\title{
Sea-level change and free gas occurrence influencing a submarine landslide and pockmark formation and distribution in deepwater Nigeria
}

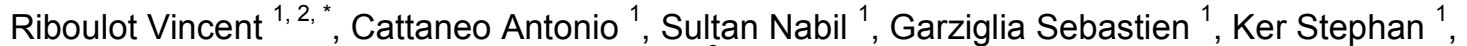 \\ Imbert Patrice ${ }^{3}$, Voisset Michel ${ }^{1}$
}

${ }^{1}$ IFREMER, Ctr Brest, Inst CARNOT EDROME, Brest, France.

${ }^{2}$ Univ Perpignan, F-66025 Perpignan, France.

${ }^{3}$ TOTAL, Pau, France.

* Corresponding author : tel.: +33 298224257 ; fax: +33 298224570 ;

email address : riboulot@ifremer.fr

\begin{abstract}
:
A series of pockmarks observed at the seabed matches well the perimeter of a large submarine landslide, called NG1, located on the outer shelf and continental slope of the Eastern Gulf of Guinea. NG1 extends over $200 \mathrm{~km} 2$, is covered by a 120-m thick sedimentary layer which tapers downslope, and has an internal structure clearly identified in 3D seismic data consisting of three adjacent units on the upper continental slope. The pockmarks above NG1 have a diameter of several tens of meters and reveal distinct origins: (1) linked to $>500 \mathrm{~m}$ deep fluid reservoirs, (2) rooted in NG1 internal discontinuities between NG1 units, and (3) well above NG1, superficially rooted in a regional conformity (D40), which marks the lowest sea level of the Marine Isotope Stage 6. The regional stratigraphic pattern of the study area is composed of muddy sedimentary sequences separated by correlative conformities and transgressive condensed units of coarser grain size. Mud-confined coarser-grained units constitute transient gas reservoirs favoring lateral gas migration and formation of pockmarks rooted in the condensed units. The buried NG1 landslide modifies the layered structure of the sedimentary column providing (1) overall, a barrier to fluid migration, and (2) localized pathways for fluid migration. The triggering factor for the formation of pockmarks above NG1 can be the variation of hydrostatic pressure driven by relative sea-level fall during Marine Isotopic Stages 6 and 2 and consequent gas exsolution and fluid flow. We anticipate our result to be a starting point for understanding the role of gas seeps on climate change worldwide. Furthermore, gas release intensifies during lowstands with relevant implication on global warming after ice ages.
\end{abstract}




\section{Highlights}

- This is the first study linking the effect of a landslide on gas migration pathways. Pockmark formation is reconstructed with geophysical and geotechnical data. The landslide occurred during a sea-level fall period. The timing of pockmark formation is in part controlled by 100-kyr eustatic cycles. - Once buried, the landslide controls the spatial organization of pockmarks.

Keywords : pockmarks, fluid seepage, submarine landslide, sea-level changes, piezocone, Niger Delta

\section{Introduction}

Since the 1970s, studies of the ocean floor have revealed the presence of pockmarks on passive and active continental margins worldwide. Pockmarks are described as circular or near circular depressions, generally 10-200 m in diameter and some tens of meters in depth, but they may reach $1.5 \mathrm{~km}$ in diameter and $150 \mathrm{~m}$ in depth (Pilcher and Argent, 2007). When pockmarks are observed in vertical section (seismic profile), they are associated with a vertical chimney under the depression (Hustoft et al., 2007). In seismic sections, chimneys are characterized by either an interruption of seismic reflectors due to the gas charge (wipeout zone) (Hovland, 1983, Hovland, 1991 and Rao et al., 2001), or by an inflection of seismic reflectors (Hovland et al., 1984) corresponding to a velocity pull down effect or to a deformation of sedimentary layer where fluids migrate.

Since the first study about pockmarks (King and MacLean, 1970), where they were considered as randomly distributed features at the seafloor, their understanding has evolved. It is now widely accepted that pockmarks represent the morphological signature of fluid seepage (Hovland et al., 1984), where fluid may be biogenic and/or thermogenic gas (Rogers et al., 2006) or water (Harrington, 1985). During recent years, there has been much interest in the study of pockmarks because they represent potential pathways for important quantities of gas from sediments to the oceans (e.g. Vogt et al., 1999, Paull et al., 2002, Ussler et al., 2003, Dimitrov and Woodside, 2003, Hovland et al., 2002, Hovland et al., $\underline{2005}$ and $\underline{\text { Gay et al., 2006a). }}$ 
The discovery of pockmark alignments has shown that their spatial organization may be the result of fluid seepage from underlying sedimentary structures such as fault systems, channels, mud volcanoes, mud diapirs, and glaciogenic deposits (e.g. Eichhubl et al., 2000; Pilcher and Argent, 2007; Forwick et al., 2009). The spatial distribution of pockmarks suggests that all the discontinuities affecting the sedimentary column represent potential drains for fluid flow, and that simple diffusion through the sediments cannot explain such structures (Abrams, 1992; Brown, 2000). Today it is recognized that pockmarks can be subdivided in two groups: non-random pockmarks, when their spatial distribution is related to identified buried geological features, and random pockmarks, when it is not (Pilcher and Argent, 2007).

The mechanisms behind pockmark formation are still poorly understood. Some hypotheses and conceptual models about pockmark formation have been proposed by various authors (eg. Josenhans et al., 1978; Hovland, 1987; Gay, 2002; Cartwright et al., 2007, Andresen et al., 2008, Cathles et al., 2010). Josenhans et al., (1978), Hovland (1987), and Gay (2002), for example, propose schematic models of pockmark formation involving gas pressure in a transient fluid reservoir, local sedimentation, and action of bottom currents, but are insufficient to have a comprehensive view of all factors governing fluid expulsion.

Many studies suggest the possible implication of mass transport complexes in pockmark development (Trincardi et al., 2004; Bayon et al., 2009; Plaza-Faverola et al., 2010; Sun et al., 2012), but the role of a landslide in the distribution and formation of pockmarks has never been the central subject of a study. The Eastern Niger Submarine Delta (ENSD; Fig. 1), situated in deepwater "Niger Delta", deserves attention because: (1) there is significant evidence for fluid migration at the seabed (Bayon et al., 2007; 2011; Sultan et al., 2007b; 2010; 2011; Riboulot et al., 2011a); (2) the sedimentation is affected by gravity processes (Sultan et al., 2007a; Garziglia et al., 2010; Ker et al., 2010; Riboulot et al., 2012); and (3) the age and main controlling parameters of regional sedimentation for the late Quaternary are known (Riboulot et al., 2012). The upper-most five depositional sequences of the ENSD were formed during the last ca. $500 \mathrm{kyr} \mathrm{BP}$, in response to glacial/interglacial fluctuations driven by 
100-kyr Milankovitch cycles. Fluid seepages are expressed at the seabed by the presence of pockmarks, gas hydrates, mud volcanoes and carbonate constructions (eg. Damuth, 1994; Cohen and McClay, 1996; Hovland et al., 1997; Brooks et al., 2000; Graue, 2000; Deptuck et al., 2003; Sultan et al., 2007; 2010).

This study presents the influence of the overall stratigraphic organization of the ENSD and of a buried landslide on fluid migration and pockmark generation. Based on the combined analysis of industrial 3D seismic data, scattered 2D seismic lines, sedimentological and geotechnical data (Cone Penetration Tests with pore pressure measurements, CPTu) a conceptual model is proposed to present the age of sedimentary units hosting pockmarks, to explain the origin of pockmarks from transient reservoirs at sequence boundaries and to assess the role of a landslide versus gas seeps.

\section{Regional setting}

\subsection{The Niger Delta}

The continental margin off the Niger Delta, named 'Niger Delta' by oil companies (e.g., Damuth, 1994, Corredor et al., 2005 among others), 'Niger Delta complex' (Oomkens, 1974) or 'Greater Niger Delta area' (Morley et al., 2011) is undergoing gravity-driven deformation due to the presence of a mobile substratum at the base of the sediment fill (Damuth, 1994; Bilotti and Shaw, 2005; Corredor et al., 2005). This substratum is formed by Early Tertiary overpressured shale deformed since the Oligocene (Wiener et al, 2006).

The continental shelf of the 'Niger Delta' is characterized by an extensional zone dominated by large offset listric normal faults (synthetic and antithetic) (Damuth, 1994; Morley and Guerin, 1996). The upper and middle continental slope represent a translational zone (Damuth, 1994) dominated by folding and faulting in response to rapid sedimentation rates and shale remobilization (Doust and Omatsola, 1990; Morley and Guerin, 1996). As the thick stratigraphic column slowly moved downslope (Morley and Guerin, 1996), the lower slope is characterized by a compressional zone (Damuth, 1994) dominated by a series of linear toethrusts forming a fold-and-thrust belt. On the Nigerian continental slope, fluid seepage 
activity is expressed by the presence of pockmarks, gas hydrates, mud volcanoes and carbonate build-ups (Damuth, 1994; Cohen and McClay, 1996; Hovland et al., 1997; Brooks et al., 2000; Graue, 2000; Deptuck et al., 2003; Sultan et al., 2007; 2010; Riboulot et al., 2011a).

\subsection{The Eastern Niger Submarine Delta}

The study area is on the continental shelf and slope of the ENSD, roughly $65 \mathrm{~km}$ offshore, between 150 and $800 \mathrm{~m}$ water depth, and it covers $2350 \mathrm{~km}^{2}$. Three prominent structural folds are formed by shale-cored anticlines expressed by collapse normal faults faintly discernable at the seabed (folds EA, EB, EC, Fig. 1). These shale-cored folds delimit a large corridor where submarine landslides and fluid-migration features are present.

The ENSD consists of a stack of mud-dominated sedimentary sequences separated by marked erosional surfaces on the continental shelf (D10, D20, D30, D40 and D50 from bottom to the top; Fig. 2a). The shelfal unconformities, formed during sea level falls and lowstands, correspond seaward to correlative bounding conformities that have regional extent. The conformities are marked by high amplitude reflectors in seismic data and correspond to thin sedimentary units, deposited during sea level rise periods, relatively coarser-grained than over and underlying sediment (Riboulot et al., 2012).

Pockmarks in the ENSD are related to gas hydrate dissolution/dissociation, dewatering, presence of fault systems, buried mass transport complexes and fluid escape from petroleum reservoirs (eg., Sultan et al., 2010; 2011; Riboulot et al., 2011a). A large number of pockmarks is observed on the bathymetric map above a Mass Transport Complex called NG1 and mapped in Garziglia et al. (2010).

\subsection{The NG1 landslide}

Previous studies by Garziglia et al. (2010); Ker et al. (2010) and Riboulot et al. (2012) present a large landslide called NG1 buried in the corridor between the three shale-cored folds of the ENSD (Fig. 1). The most proximal deposits of this landslide are at the outer shelf where Riboulot et al. (2012) highlighted the occurrence of shoreface sedimentary prisms 
deposed during sea level lowstands. NG1 extends down to the mid slope, covering an area of $\sim 200 \mathrm{~km}^{2}$ for an estimated volume of at least $\sim 12 \mathrm{~km}^{3}$. NG1 affects the whole depositional sequence S2 between the seismic reflectors D10 and D20, the latter being ascribed to a silty/sandy layer deposited during the sea level rise between MIS10.2 and MIS9.3 (Riboulot et al., 2012). The fact that this silty/sandy layer has been disrupted but kept its stratigraphic position suggests that it has undergone little deformation during the emplacement of the NG1 landslide (Ker et al., 2010).

\subsection{Seismic signature of gas in marine sediment}

144 The localized accumulation of free gas in marine sediments often yields anomalous seismic signatures, making seismic methods a useful tool for the identification and characterization of the sub-seafloor 'plumbing system' beneath seep sites. Gas may appear as amplitude enhancement or suppression (e.g. Judd and Hovland, 1992; Gay et al., 2007; Netzeband et al., 2010), as well as through the disruption of seismic reflections often referred to as "acoustic turbidity" (e.g. Judd and Hovland, 1992; Schroot and Schüttenhelm, 2003; Mathys et al., 2005; Schroot et al., 2005; Gay et al., 2007; Jones et al., 2010), and/or as "disturbed zones" (Schroot and Schüttenhelm, 2003). Amplitude enhancement of sedimentary or structural features (i.e., "bright spots") may occur when gas preferentially accumulates in highly permeable layers or structural voids such as faults (e.g. Taylor et al., 2000; Tréhu et al., 2004). The term "gas chimney" is widely used to refer to vertical/sub-vertical regions of suppressed reflectivity (e.g. Gorman et al., 2002; Haacke et al., 2008) or of enhanced reflectivity (e.g.

157 Schroot and Schüttenhelm, 2003; Gay et al., 2007) caused by gas. The presence of gas 158 creates an inflection of seismic reflectors due to a diminution of the acoustic wave velocity. Moreover, the lack of reflection in the chimney may occur due to physical disruption of sedimentary layering by migrating, gas-charged pore fluids (e.g. Davis, 1992; Gorman et al., 2002), or by highly-reflective overlying interfaces that significantly reduce the transmission of energy (e.g. Judd and Hovland, 1992; Garcia-Gil et al., 2002; Sager et al., 2003). 


\section{Database and Methods}

164

165

166

167

168

169

170

171

172

173

174

175

176

177

178

179

180

181

182

183

184

185

186

187

188

189

\subsection{Geophysical data}

The primary source of data is conventional, industrial 3D seismic reflection data provided by TOTAL. These data come from three reprocessed exploration 3D seismic surveys having an inline and crossline spacing of $12.5 \mathrm{~m}$. The dominant frequency of the seismic data is $70 \mathrm{~Hz}$ in the upper $100 \mathrm{~ms}$, giving a vertical resolution of $\sim 10.5 \mathrm{~m}$ (at a velocity of $1500 \mathrm{~ms}^{-1}$ ). The bathymetry used to characterize seafloor morphologies is extracted from seafloor-reflector picking within 3D seismic data and has horizontal resolution of $12.5 \mathrm{~m}$ (Fig. 1).

Additionally, High Resolution 2D seismic data were acquired during the ERIG3D cruise using the SYSIF, a recently developed deep-towed acquisition system (Marsset et al., 2010; Ker et al., 2010). With acoustic transducers working in the $580-2200 \mathrm{~Hz}$ frequency range, and a 15 $\mathrm{m}$ long dual channel streamer, the SYSIF provides images of the first $100 \mathrm{~ms}$ twtt below seafloor with a resolution of about $0.5 \mathrm{~m}$.

\subsection{Seismic attribute analysis}

Seismic data were processed on a workstation and the seismic interpretation and attribute analyses were performed with the SISMAGE software developed by TOTAL (Guillon and Keskes, 2004 - Fig. 3 and Appendix A). The 3D seismic data were pre-stack time migrated and short-offset processed. Then, following the identification and initial mapping of key horizons, SISMAGE was used to calculate isopach and attribute maps. Dip and amplitude attributes were extracted along specific horizons. Other maps were obtained by extracting amplitude, coherency and fault attributes from intervals between two horizons. Such an approach requires previous processing of a coherency and fault cube in SISMAGE (Gay et al., 2006b). As summarized by Bull et al. (2009), the analysis of isopach and attribute maps from a geomorphic perspective is key in deciphering the characteristics of depositional units.

\subsection{Sediment core data}

Calypso piston cores CS18 and CS31 were obtained from the continental slope of the ENSD in 753 and $762 \mathrm{~m}$ water depth, respectively (Tab. 1). Sediment core analysis included 
physical property measurements (gamma density, P-wave velocities, magnetic susceptibility with a Geotek Multi Sensor Core Logger - MSCL), sedimentological description and continuous major element analysis $(\mathrm{Ca}, \mathrm{Sr}, \mathrm{Ti} \ldots)$ with an Avaatech XRF core scanner (Richter et al., 2006). Based on the evaluation of coring parameters during operations using "CINEMA" software (Bourillet et al., 2007), sediment perturbation during coring is considered as negligible. The core data acquired in this study are correlated to seismic reflection profiles and physical and geochemical logs presented in Riboulot et al. (2012).

\subsection{In situ geotechnical measurements}

In situ geotechnical measurements (Cone Penetration Tests with pore pressure measurements, CPTu) were carried out with the Penfeld penetrometer. This device developed by Ifremer allows to perform piezocone tests as deep as 30 meters below the seafloor (details in Sultan et al., 2010). The Ifremer piezometer (details in Sultan et al., 2011) was also used to measure the in situ pore pressure at two different sites during more than one year. Calypso cores, piezocones, and piezometers characteristics are presented in Table 1.

\section{Results}

\subsection{Morphological description of the buried NG1 landslide}

The NG1 submarine landslide is located in a corridor delimited to the west and to the east by the shale-cored folds EC and EA respectively, and it is limited by the shale fold EB to the south in about $800 \mathrm{~m}$ water depth (Figs. 1, 2 and 3 and Appendix A). The source area of the NG1 landslide is delimited to the north in about $200 \mathrm{~m}$ water depth by the shelf edge and growth faults affecting the seabed and described in Damuth (1994) as the extensional zone of the Niger Delta. NG1 is buried under about $120 \mathrm{~m}$ of sediment on the upper slope, but the thickness of the overlaying sediments progressively decreases to about $20 \mathrm{~m}$ at mid slope on the flank of the shale-cored fold EB. NG1 affects the sedimentary sequence S2 between seismic reflectors D10 (below) and D20 (Fig. 2a). The seismic reflector D10 at the base of NG1 is mostly continuous and concordant with the underlying sedimentary layers (Fig. 2). 
217 The seismic reflector D20 is more discontinuous although always traceable at the top of

218 NG1. In some areas, D20 appears as a sharp, smooth surface, while in other areas it has a 219 rough, hummocky geometry (Figs. 2, 3a and Appendix A1). The discontinuous character of D20 reflector, showing the thin coarser sedimentary unit deposited during a sea level rise period is discontinuous too, demonstrates that the landslide occurred after this highstand period. NG1 body is generally characterized by lower amplitude, more discontinuous and chaotic seismic reflections (Fig. 3b and Appendix A2 and 3). The isopach map of the seismic sequence S2 bounded by reflectors D10 and D20 reveals the complex morphology of NG1 by showing that its thickness varies from about $10 \mathrm{~m}$ to $70 \mathrm{~m}$ (Fig.3c). By combining analyses of vertical seismic sections, isopach and attribute maps, NG1 can be divided into four major areas from north to south (Fig. 3 and Appendix A):

- Area 1 is the source area at the shelf edge. There the clinoforms of a sedimentary prism show evidence of tilted blocks and loss of sediment (Fig. 2a: close-up view). So a part of the shoreface prism has been reworked after its deposition, but before the deposition of the following shoreface prism entirely preserved under reflector D30.

- Area 2 in the upper slope, close to the shelf edge, is characterized by a substantial overthickening and reworking of sequence S2 (Fig. 3b and c and Appendix A2 and A3).

- Area 3 shows sharp lateral variations (from west to east) in thickness and seismic facies allowing to distinguish a western, a central and an eastern unit (Figs. 2b, 3 and 4a).

- Area 4 represents the distal part of NG1 on the flank of the shale-cored fold EB. There the sequence $\mathrm{S} 2$ is also substantially overthickened.

Seismic analysis suggests that the degree of sediment deformation in Area 4 is comparable to that of Area 2 and of the western and eastern units of Area 3. Area 3 constitutes the main part of the landslide deposit on the upper continental slope. Its central unit has a homogeneous seismic facies with evident layering and without faults (Figs. 2b, $3 a$ and

242 Appendix A3). The seismic facies is coherent/consistent (Fig. 3b). The two lateral units, the 243 western unit and the eastern unit, display two convex-downslope lobe like geometries (Figs. $2442 \mathrm{~b}$ and 3). Based on the analysis of isopach, coherency and fault attribute maps, it is in these 
lobes that the most severe deformation occurred. A far lower degree of deformation can be inferred from the homogeneous, layered seismic facies characterizing the central unit of Area 3. Moreover, the seismic reflectors at the top (D20) and base (D10) of NG1 are of higher amplitude in the central unit than in the two bounding lateral units. It is also noteworthy that the central unit is comparable in thickness to undisturbed sediment out of the landslide (Figs. 2b, 3c and Appendix A1).

\subsection{Silty/sandy layers below and above NG1}

252 The 2D HR seismic profiles show several reflectors characterized by high amplitude 253 corresponding to correlative conformities of sequence boundaries identified on the shelf (Fig. $2545 a$ and Appendix B). Reflectors D10, D30 and D40 are relatively continuous with local 255 interruptions due to fluid chimneys, while D20 is a discontinuous reflector at the top of NG1 landslide deposit (Fig. 5a and Appendix B). The D10 seismic signature is similar to signatures of enhanced reflections caused by lateral and vertical fluid migration described in the literature (e.g., Sun et al., 2012 and references therein). In situ piezocone data show that the high amplitude reflectors D10 and D20 correspond to silty/sandy layers because they are characterized by high tip resistance, high friction and low pore pressure (see CPT09S07 and CPT09S08 data in Fig. 5). The reflector D40 is not detected by in situ piezocone data.

Calypso core CS18 intersects the regional reflector D40 and shows that its high amplitude can be correlated to a silty/sandy layer at $7 \mathrm{mbsf}$. The gamma density of this silty/sandy layer measured in the core is $1.650 \mathrm{~g} . \mathrm{cm}^{-3}$. Figure 5 a shows that core CS18 reaches NG1 deposits below reflector D20 marking its top at 17 mbsf. In agreement with piezocone results, core analysis reveals that D20 reflector corresponds to a silty/sandy layer (Fig. 5a).

The calypso core CS31 (10.56 m long) was collected outside NG1 (Fig. 5 and Appendix B). mbsf in core CS31 cannot be correlated to the seismic reflector D40, which intersects the

271 core at about 8 mbsf. The gamma density of the silty/sandy layer measured in the core has 272 relatively low values $\left(1.500 \mathrm{~g} . \mathrm{cm}^{-3}\right.$; Fig. $\left.6 \mathrm{~b}\right)$, probably due to its thinning on the eastern flank 
273 of fold EB: this same interpretation could account for the lack of expression of D40 in 274 piezocone CPT09S08 close to core CS31.

\section{$275 \quad$ 4.3 Pockmarks}

276 Pockmarks occur in an area of $175 \mathrm{~km}^{2}$ between folds EA and EC in water depth of 500 to $277700 \mathrm{~m}$. Some 376 pockmarks reach the seafloor, while 155 pockmarks are buried. They are 278 all regular circular features with diameter of several tens of meters (Figs. 4b, 4c and 6). They 279 vary in diameter from several meters to a maximum of $200 \mathrm{~m}$, while the depth of the 280 depression at the seafloor may reach $25 \mathrm{~m}$. The pockmark density in the study area is 281 approximately $2.15 / \mathrm{km}^{2}$, higher than the concentration described by Pilcher and Argent, 282 (2007) on the west African continental margin, but lower than densities described in other 283 areas (e.g., Fader, 1991; Foland et al., 1999; Hovland and Judd, 1988).

284 In the study area, we distinguish three groups of pockmarks based on their distribution and 285 origin: 1) random pockmarks (RP) deeply rooted in the sedimentary column; 2) random pockmarks rooted in the conformity surface D40; and 3) non-random pockmarks (NRP) in connection with the NG1 landslide (Fig. 6d).

\subsubsection{Deeply rooted random pockmarks}

289 We identified as random pockmarks 114 out of the 531 pockmarks present in the study area 290 (21\% of the total number of pockmarks). Random pockmarks are regular cone-shaped pockmarks with a diameter ranging from 10 to $200 \mathrm{~m}$. Some of them occur at the seafloor while other are buried (Fig. 4c). Most of these pockmarks occur in the southern portion of Area 3 and they are restricted to areas affected in depth by small shale folds (Fig. 6c). They seem rooted on these small folds. Some chimneys associated to the random pockmarks cross the NG1 landslide, others terminate in the sedimentary layers underlying NG1 (Fig. 6c). The vertical chimney of this group of pockmarks can be up to $200 \mathrm{~m}$ high. Chimneys are characterized by a downward deflection or an interruption of seismic reflectors. 
299 We count 263 pockmarks out of the 531 in the study area (49\% of the total number of 300 pockmarks of the study area) that affect only the youngest sequence S5 with chimneys 301 rooted in the D40 reflector. These pockmarks are similar in morphology to all the others, but 302 have smaller sizes; their diameters range from 10 to $100 \mathrm{~m}$ with a depth less than $10 \mathrm{~m}$ 303 (Figs. 4 and 6). Vertical chimneys of this group of pockmarks cross-cut the whole sedimentary sequence S5 so they are about $50 \mathrm{~m}$ high. Chimneys are characterized by 305 downward deflections and low amplitudes of seismic reflectors. The 2D HR seismic dataset provides better images of pockmark chimneys that are undoubtedly rooted in the D40 reflector (Fig. 7 and Appendix B).

\subsubsection{Non-random pockmarks linked to NG1}

A series of NW-SE alignments of pockmarks matches with the perimeter and the internal structure of NG1 landslide (Fig. 4c). These pockmarks are rooted in the discontinuities present within the NG1 landslide, at the limits between the western, central and eastern NG1 internal units and may either reach the seafloor or end in the D40 reflector (Fig. 6). Nonrandom pockmarks linked to NG1 are sub-circular seafloor depressions corresponding in depth to seismic reflector packages with a local downward deflection. Their crater has a diameter of 10 to $140 \mathrm{~m}$ with a depth of about ten meters.

In total we note 154 pockmarks, $29 \%$ of the total number of pockmarks of the study area, whose chimney begins in discontinuities within NG1 landslide at the contact between the three internal units (Western, Central, and Eastern). Of these 154 pockmarks, 85 are rooted at the transition between NG1 and the surrounding sediments, that is along NG1 perimeter, while 69 originate in correspondence with the limits of the internal units (Fig. 4c). In addition, of these 154 pockmarks, 87 end up on the surface D40 and 67 at the seabed.

Chimneys of this group of pockmarks are characterized by a downward deflection or an interruption of seismic reflectors associated to an alternation of low and high amplitude anomalies in the center of the chimneys (Fig. 6). Figure 7 shows more precisely the rooting 
325 of the chimney in NG1 landslide. The chimney of the non-random pockmark appears 326 transparent with an interruption of seismic reflectors between D20 and D40. At D40, the 327 pockmarks observed in this seismic section are completely infilled. The chimney of the last sequence rooted in the upstream flank of the D40 pockmark is characterized by an inflection of the seismic reflectors. The observations about the repartition of pockmarks in the sedimentary column are summarized in Figure $6 \mathrm{~d}$.

332 Long-term piezometers deployed at PZS13 and PZS14 sites (Figs. 1, 5 and Appendix B) 333 aimed to detect any potential fluid activities in the most frontal part of NG1, where 334 deformation processes are active today (Garziglia et al., 2010). PZS13 and PZS14 data are 335 presented in Figure 8 and show relatively limited pore pressure fluctuations during the almost 1-year long monitoring period. However, data from Figure 8 confirm the presence of free gas at the top of NG1. In fact, piezometer data show that at given locations pore pressure perturbations occur in 12-hours cycles and 15-days cycles. The pore pressure fluctuates with semi-diurnal tides and with the spring/neap tides. It is important to mention that the tidal cycles effect on differential pore pressure sensors is an indication of the increase of the compressibility of the pore fluid and, therefore, demonstrates the presence of free gas in the pore fluid. Figure 8 shows that free gas is present at levels P3, P4 and P5 for PZS 13 and levels P2, P3, P4 and P5 for PZS14.

344 For PZS13, pore pressure fluctuations generated by the 15-days tidal cycle recorded by P3, 345 P4 and P5 show that the highest amount of free gas occurs at P3 (Fig. 8a) which fits with the 346 D40 reflector (see Fig; 5 and Appendix B).

347 Data recorded by PZS14 (Fig. 8b) show the 15-days tidal cycle recorded by P2 to P4. Here, 348 the highest amount of free gas occurs at P4 and P5, which are located around D10 and D20 349 reflectors. Moreover, pore pressure increases during almost two months at P2 level (between the 27th of May and the 29th of July 2008 - Fig. 8b). The fluid accumulation is followed by 351 long-term, smooth pore-pressure dissipation (between the 29th of July and the 1st of October 352 2008). The $\mathrm{P} 1$ sensor of PZS14 has recorded during almost the same period (14th of June to 
1st of October 2008) a small depression (pressure lower than hydrostatic) which may indicate gas bubbles rising up and generating a decrease of the hydrostatic pressure due to the low gas density.

\section{Discussion}

\subsection{The role of silty/sandy layers in muddy successions}

A thin permeable silty/sandy layer between two layers that have very low permeability could act as a reservoir of fluid or preferential fluid conduit as it was suggested in the eastern flank of the shale-cored anticlines EB (Sultan et al., 2011). There are two possible transient storage zones of gas in the study area based on seismic data, sediment cores and in situ piezocone and piezometer measurements: (1) the first reservoir is located under the NG1 landslide and corresponds to the silty/sandy sedimentary unit marked by reflector D10 (Figs. $5 a$ and 6); (2) the second reservoir is formed by the coarse grain-size sedimentary layer marked by seismic reflector D40 on seismic data but the very high resolution of the seismic line presented in figure 7 show this layer is above the reflector D40. This upper reservoir is marked in 3D seismic data by a very high amplitude reflector (Figs. 2, 4 and 6), in core and CPTu data by a silty/sandy layer and in piezometer data by the presence of free gas. This layer was deposited during the sea level rise that followed the MIS 6 glacial interval (Riboulot et al., 2012).

\subsection{The interplay of NG1 landslide and fluids within sediment}

Data presented in this study complete the interpretations of Garziglia et al., 2010 and Ker et al., 2010 and suggest a possible link between fluid dynamics and NG1 landslide. Some lines of evidence in support of this link are listed below:

- Pockmarks are localized in the most deformed area of NG1 and at the discontinuities between the NG1 internal units (Fig. 4c). Indeed, the Area 3 of NG1 in the upper continental slope is composed of three units. The central unit is much less affected by deformation than the two peripheral units: it is layered and underwent a translational motion to the south without changing its original structure. The internal discontinuities 
between the three parts are the preferential pathways for fluid migration.

- NG1 landslide overlays a silty/sandy permeable layer (seismic reflector D10) with evidence (piezometer and seismic data interpretation) of fluid circulations and free gas occurrences (Figs. 5, 6, 8 and Appendix B). This basal layer, covered by impermeable shale layer, can play the role of gas storage area.

- Sediment failure of NG1 landslide occurs during sea level fall where free and

Fluids use preferential migration pathways such as discontinuities created by a landslide to migrate to the surface as outlined by the geographical distribution of the pockmarks rooted in the NG1 landslide (Fig. 4C) and the rooting of many chimneys in NG1 landslide (Fig. 7). This is consistent with models for pockmark conduits as pipe-like zones of enhanced fracturing (Cartwright et al., 2007; Moss and Cartwright, 2010; Løseth et al., 2011), where certain hydrodynamic conditions dynamically re-open pathways from the available fracture network permitting a renewed phase of focused fluid expulsion and pressure bleed-off (Moss et al., 2012). Submarine landslide deposits can influence fluid circulation within the sediments in various ways: they can release their intrinsic fluids, play the role of impermeable caprock of fluid reservoir (Plaza-Faverola et al., 2010; Dugan, 2012), play the role of gas storage zone (Sun et al., 2012), or create preferential pathways for focused fluid flow (Bayon et al., 2009). Landslide deposits may have low porosity in comparison to the encasing hemipelagic sediments, and may thus result in enhanced consolidation related to shear deformation (Dugan, 2012). Our observations and interpretations show that NG1 landslide deposit has both played the role of impermeable caprock and created discontinuities in sedimentary layers acting as preferential migration pathway for gas to migrate to the surface: this fact depends on the intrinsic small-scale variability and complexity of landslide deposits. It can be noted that vertical chimneys, rooted in NG1 and ending in D40 (Fig. 7), can form a highpermeable vertical zone, analogous to what is called a "seal bypass system" (Cartwright et 
al., 2007), where fluids and gas can be transported faster than would otherwise be allowed by the normal permeability in the pore network of the sediments. High fluid overpressure opening a hydro fracture through low permeable sediments is a common first phase of all these bypass structures (Arntsen et al., 2007; Cartwright et al., 2007; Løseth et al., 2009; Rodrigues et al., 2009).

\subsection{The role of sea level fluctuations}

414 Many studies suggest that landslides occurred during periods of rapid sea-level rise (e.g. 415 Maslin et al., 2004; Quidelleur et al., 2008; Georgiopoulou et al., 2010; McGuire, 2010; Smith 416 et al., 2011). Maslin et al. (2004) maintained that, based on landslide volume, $70 \%$ of 417 continental slope failures during the last 45,000 years occurred in periods of rapid sea-level rise. Certainly, the time distribution of submarine landslides is uneven, more frequent during or shortly after the last glacial/deglaciation period and probably dominated by glacial cycles and related phenomena (Lee, 2009). Landslides triggered during sea level fall period include among others Ana Slide (Berndt et al., 2012; Lafuerza et al., 2012) and the present study.

422 The spatial match between the NG1 landslide and fluid flow indicators strongly suggests that 423 fluid migration has played a role in the destabilization of slope sediments in the ENSD, and 424 reminds of previously suggested relationships between repeated destabilization and fluid flow in the Eivissa Channel (Berndt et al., 2012; and references therein). This relationship was proposed also for the Storegga Slide off mid-Norway, where the most deeply incised slope failures occur precisely above a leaking gas reservoir (Bünz et al., 2005). A plausible mechanism at the origin of the NG1 event could be the presence of free and dissolved gas in 429 the basal silty/sandy layers marked by D10 reflector. The decrease of hydrostatic pressure 430 generated by sea level fall could have induced an important increase in pore pressure and 431 therefore an important decrease of the effective stress. The shear strength of sands is 432 directly linked to the effective stress (no cohesion), and an important decrease of the 433 effective stress can cause sediment to slide even with an extremely reduced initial slope. 434 Indeed, pore pressure accumulation may cause liquefaction of sand.

435 The main cause of overpressure generation on passive margins is disequilibrium compaction 
436 due to rapid and high sedimentation (eg. Flemings et al., 2008; Talukder, 2012). In most 437 cases, the generated overpressure is not sufficient to induce hydrofracturing in the 438 overburden to initiate focused fluid flow. This requires external factors, and tectonic stress 439 appears to be the most efficient trigger mechanism for seeps (Talukder, 2012). The overpressure could be due to sea level fall (Lafuerza et al., 2009). Recent studies suggest 441 the possible impact of sea level changes to explain the origins of pockmarks (Lafuerza et al., 442 2009; Hammer et al., 2010; Andresen et al., 2011; Plaza-Faverola et al., 2011). Sea-level fall 443 appears to be the most efficient trigger mechanism for pockmark formation as it was 444 suggested in the Lower Congo Basin (Andresen et al., 2011) and in the Nyegga region, 445 offshore Norway (Plaza-Faverola et al., 2011) where pockmark activity appear to coincide 446 with sea-level fall periods. Indeed, relative sea-level changes modify hydrostatic pressure: when the sea level falls, gas volume in fluid reservoir increases, and the formation of gas 448 bubbles may induce pockmark formation (Lafuerza et al., 2009).

449 Riboulot et al., (2011b) show that late Quaternary sea-level changes with 100-ky cyclicity are 450 one of the main driving factors in pockmark formation in the Gulf of Lions and possibly 451 elsewhere. This control of 100-ky cyclicity in pockmarks development is deduced from the 452 observation that pockmarks affect well-identified and discrete stratigraphic units and function episodically during the final phase of lowstand periods and the onset of sea level rise 454 (Riboulot et al., 2011b). Also in the ENSD most of the observed pockmarks are present 455 within stratigraphic units bounded by surfaces that correspond to times of sea-level changes 456 (and in particular of sea level fall; Figs. 6a and 7). The drop in sea level of about $100 \mathrm{~m}$ 457 during the Marine Isotope Stage 6 could be the cause of overpressure in gas storage zones 458 underlying the NG1 landslide, which creates a fracture in the overlying sedimentary layers or 459 reactivate pre-existing discontinuities like those creating by the NG1 gravity sliding. 460 Pockmark formation may occur in the catastrophic way initially proposed by Hovland (1987). 461 The same process during the Marine Isotope Stage 2 could originate pockmarks observed at 462 the seabed and rooted either in D40 or in D10 surfaces. 
464 For the formation of pockmarks above the NG1 landslide, we propose a scenario consisting 465 of five phases taking into account temporary gas storage, preferred pathways of gas 466 migration, the role of sediment deformation and failure, and the influence of relative sea-level 467 changes.

468 Phase 1 (Fig. 9a) - The origin of pockmark formation is linked to the presence of faults 469 crossing gas-bearing sedimentary units, similarly to what has been proposed elsewhere by 470 several independent studies (e.g., Papatheodorou et al. 1993; Boe et al. 1998; Soter, 1999; 471 Pilcher and Silver, 2007; Forwick et al., 2009). This process can cause the formation of two 472 types of pockmarks: the fault-strike pockmarks and the fault hanging-wall pockmarks (Pilcher 473 and Silver, 2007).

474 Phase 2 (Fig. 9b) - A condensed layer is formed during sea level rise on top of lowstand shoreface prisms and coeval distal marine deposits. After burial, the condensed layer with grain size coarser than encasing sediment becomes a potential fluid reservoir. This is the 477 case, for example of the condensed unit marked in seismic data by the reflector D10.

478 Phase 3 (Fig. 9c) - During the following sea level fall, the decrease of the hydrostatic 479 pressure in the transient fluid reservoir above D10 induce an important increase of the pore 480 pressure and therefore an important decrease of the effective stress. This layer becomes a weak layer; a part of the continental slope is destabilized reaching the outer shelf. The NG1 landslide has a complex internal organization with distinct less permeable units (due to 483 partial reworking of sediments during sliding) and discontinuities between the units that 484 constitute preferential paths for fluid escape.

485 Phase 4 (Fig. 9d) - After two 100 kyr climatic cycles, the landslide is buried and the underlying sedimentary layer has charged again in gas. During the lowstand MIS 6.2, many pockmarks are formed through the discontinuities created by the NG1 landslide. The presence of a landslide deposit with less permeable layers and internal discontinuities may influence both gas pressure increase, and gas release through preferential paths. The 490 presence of a landslide becomes the controlling factor of the non random organization of 
pockmarks.

492 Phase 5 (Fig. 9e) - During the lowstand MIS2.2, the mechanism of pockmark formation 493 linked to NG1 is the same as in Phase 4. In addition, the migration of gas through the NG1 494 discontinuities feeds a second transient fluid reservoir. The layer above D40 acts as a source 495 area for random pockmark formation affecting the uppermost sequence S5. Two generations 496 of pockmarks (linked to NG1 landslide and to the layer above D40) show a marked 497 stratigraphic segregation.

\section{Conclusions}

While pockmarks have been recognized in many zones of the African coast, we extend the known range of formation processes of these features in three ways: 1) we show the relevance of the knowledge of the stratigraphic context (stratigraphic units and their age) where pockmarks are present to understand their timing and mode of functioning; 2) we link the spatial distribution and origin of pockmarks to well identified buried features: the presence of a landslide represents the main controlling factor of non random spatial organization of pockmarks in the study area; and 3) we propose that sea level changes are

506 the main controlling factor for the timing of pockmarks formation. The timing of pockmark 507 formation is in part exclusively controlled by 100-ky cyclicity, in part dependent (for deeply 508 rooted pockmarks) on the presence of deep structures.

509 Pockmarks observed in the Eastern Niger Submarine Delta (ENSD) include pockmarks rooted in a large buried submarine landslide and pockmarks linked to coarser grain size sedimentary layers formed during phases of sea-level rise. The pockmarks above the buried NG1 landslide are similar in morphological terms, but can be broadly distinguished in three 513 well identified groups: 1) deeply-rooted random pockmarks whose chimneys end under NG1

514 landslide or at the seafloor; 2) non-random pockmarks linked to the NG1 landslide (reaching 515 the seafloor and/or ending within D40); and 3) random pockmarks rooted in D40 reflector 516 marking the presence of a coarser sedimentary layer.

517 The integrated study of pockmarks provides the first detailed evidence of the implication of a 
518 landslide into the development of a pockmark field. The spatial distribution of pockmarks can

519 be controlled by a buried landslide deposit in a comparable way of pockmark alignments 520 depending on underlying channels. The processes of pockmark formation imply the 521 concomitant action of several factors: (1) a gas source, (2) preferential gas migration 522 pathways, (3) gas accumulation zones and (4) global sea-level change.

523 Our results provide useful information about the role of sea level changes and indirectly 524 climate change on gas seeps: gas release intensification during sea level lowstand can have 525 relevant implication on global warming after ice ages.

\section{Acknowledgements}

527 This work has been developed and funded by Ifremer and Total, through the ERIG3D 528 project. The support by officers and crew during the ERIG3D cruise on board R/V "Pourquoi 529 Pas ?" (2008) is greatly appreciated, as is the dedication of the Genavir and Ifremer technical 530 staff during the cruise. The identification of the nature of the pockmarks and the mapping of 531 the NG1 landslide would have been impossible without the use of reprocessed exploration 3D seismic kindly provided by TOTAL and TOTAL Nigeria Subsidiary. We also thank Bruno 533 Marsset (Ifremer) and Eric Cauquil (Total) for reviewing the manuscript and providing 534 insightful comments. We thank sincerely the reviewers J. Cartwright and C. Berndt, and the 535 editor $\mathrm{P}$. Shearer for their stimulating comments and suggestions.

\section{References}

537 Abrams, M.A., 1992. Geophysical and geochemical evidence for subsurface hydrocarbon 538 leakage in the Bering Sea, Alaska. Mar. Pet. Geol. Bull. 9, 208-221.

539 Andresen, K.J., et al. 2008. Morphology and distribution of Oligocene and Miocene 540 pockmarks in the Danish North Sea -implications for bottom current activity and fluid 541 migration. Basin Res. 20, 445-466.

542 Andresen, K.J., Huuse, M., 2011. 'Bulls-eye' pockmarks and polygonal faulting in the Lower 543 Congo Basin: Relative timing and implications for fluid expulsion during shallow burial. Mar. 544 Geol. 279, 111-127.

545 Arntsen, B., et al. 2007. Seismic modelling of gas chimneys. Geophysics 72, 251-259. 

Delta margin. Earth Planet. Sci. Lett. 312, 443-452, doi:10.1016/j.epsI.2011.10.008.

548 Bayon, G., et al. 2009. Multidisciplinary investigation of fluid seepage on an unstable margin: the case of the Central Nile deep sea fan. Mar. Geol. 261, 92-104.

550 Bayon, G., et al. 2007. Sr/Ca and Mg/Ca ratios in Niger Delta sediments: Implications for 551 authigenic carbonate genesis in cold seep environments. Mar. Geol. 241, 93-109.

552 Berndt, C., et al. 2012. Repeated slope failure linked to fluid migration: The Ana submarine landslide complex, Eivissa Channel, Western Mediterranean Sea. Earth Planet. Sci. Lett. 319-320, 65-74, doi:10.1016/j.epsl.2011.11.045.

Bilotti, F.D., Shaw, J.H., 2005. Deepwater Niger Delta fold and thrust belt modelled as a styles. AAPG Bull. 89, 1475-1491.

558 Boe R, et al. 1998. Elongate depressions on the southern slope of the Norwegian Trench 559 (Skagerrak): morphology and evolution. Mar. Geol. 146, 191-203.

Bourillet, J.F., et al. 2007. Behaviour of a piston corer from accelerometers and new insights on quality of the recovery. Proceedings of the 6th International Offshore Site Investigation and Geotechnics Conference: Confronting New Challenges and Sharing Knowledge, 11-13 September 2007, London, UK, 57-62.

Brooks, J.M., et al. 2000. The nature of gas hydrates on the Nigerian continental slope. Gas hydrates:Challenges for the future. Ann. N.Y. Acad. Sci. 912, 76-93.

Brown, A., 2000. Evaluation of possible gas microseepage mechanisms. AAPG Bull. 84 (11), 1775-1789.

Bull, S., et al. 2009. A review of kinematic indicators from mass-transport complexes using 3D seismic data. Mar. Pet. Geol. 26, 1132-1151.

Bünz, S., et al. 2005. Fluid flow impact on slope failure from 3D seismic data: a case study in

572 Cartwright, J., et al. 2007. Seal bypass systems. AAPG Bull. 91, 1141-1166.

573 Cathles, L.M., et al. 2010. The physics of gas chimney and pockmark formation, with 574 implications for assessment of seafloor hazards and gas sequestration. Mar. Pet. Geol. 27, 575 82-91.

Cohen, H.A., McClay, K., 1996. Sedimentation and shale tectonics of the northwestern Niger 577 Delta front. Mar. Pet. Geol. 13, 313-328.

578 Corredor, F., et al. 2005. Structural styles in the deep-water fold and thrust belts of the Niger 579 Delta. AAPG Bull. 89, 753-780.

580 Damuth, J.E., 1994. Neogene gravity tectonics and depositional processes on the deep 581 Niger Delta continental margins. Mar. Pet. Geol. 11, 321-346.

582 Davis, A.M., 1992. Shallow gas: an overview. Cont. Shelf Res. 12 (10), 1077-1079.

583 Deptuck, M.E., et al. 2003. Architecture and evolution of upper fan channel belts on the Niger 584 Delta slope and in the Arabian Sea. Mar. Pet. Geol. 20, 649-676. 
Dimitrov, L., Woodside, J., 2003. Deep sea pockmark environments in the eastern Mediterranean. Mar. Geol. 195, 263-276.

587 Doust, H., Omatsola E., 1990. Niger Delta. In: Edwards, J.D., Santogrossi, P.A. (Eds.), 588 Divergent/passive margin basins. AAPG Mem. 48, 201-238.

589 Dugan, B., 2012. Petrophysical and consolidation behavior of mass transport deposits from 590 the northern Gulf of Mexico, IODP Expedition 308, Mar. Geol. 591 doi:10.1016/j.margeo.2012.05.001.

592 Eichhubl, P., et al. 2000. Structural control of fluid flow: offshore fluid seepage in the Santa 593 Barbara Basin, California. J. Geochem. Explor. 69-70, 545-549.

Fader, G.B.J., 1991. Gas-related sedimentary features from the eastern Canadian continental shelf Cont. Shelf Res. 11, 1123-1153

596 Flemings, P.B., et al. 2008. Pore pressure penetrometers document high overpressure near 597 the seafloor where multiple submarine landslides have occurred on the continental slope, 598 offshore Louisiana, Gulf of Mexico. Earth Planet. Sci. Lett. 274(1-2), 269-283.

599 Foland, S.S., et al. 1999. Pockmarks along the Californian Continental Margin: implications 600 for fluid flow. Abstract. AAPG Bull. 83, 681-706.

601

602

603 604

605 606 607 608

609

610

611

612 613

Forwick, M., et al. 2009. Pockmarks in Spitsbergen fjords. Nor. J. Geol. 89, 65-77, ISSN 029196X.

Garcia-Gil, S., et al. 2002. Shallow gas features in incised-valley fills (Ria de Vigo, NW Spain): a case study. Cont. Shelf Res. 22, 2303-2315.

Garziglia, S., et al. 2010. Identification of shear zones and their causal mechanisms using a combination of cone penetration tests and seismic data in the Eastern Niger Delta. In: Mosher, D., et al. (Eds.), Submarine Mass Movements and Their Consequences - Advances in Natural and Technological Hazards Research. Springer 28, 55-65.

Gay, A., 2002. Les marqueurs géologiques de la migration et de l'expulsion des fluides sédimentaires sur le plancher des marges passives matures. Exemples dans le Bassin du Congo. Thèse de doctorat, Université de Lille 1, 426 pp.

Gay, A., et al. 2007. Geological controls on focused fluid flow associated with seafloor seeps in the Lower Congo Basin. Mar. Geol. 244 (1-4), 68-92.

Gay, A., et al. 2006a. Evidences of early to late fluid migration from an upper Miocene turbiditic channel revealed by 3D seismic coupled to geochemical sampling within seafloor pockmarks, Lower Congo Basin. Mar. Pet. Geol. 23, 387-399.

Gay, A., et al. 2006b. Isolated seafloor pockmarks linked to BSRs, fluid chimneys, polygonal faults and stacked Oligocene-Miocene turbiditic palaeochannels in the Lower Congo Basin. Mar. Geol. 226, 25-40.

Georgiopoulou, A.D.G., et al. 2010. Sahara Slide: Age, initiation, and processes of a giant submarine slide. Geochem. Geophys. Geosyst., 11, Q07014, doi:10.1029/2010GC003066.

Gorman, A.R., et al., 2002. Migration of methane gas through the hydrate stability zone in a low-flux hydrate province. Geology 30 (4), 327-330.

Graue, K., 2000. Mud volcanoes in deepwater Nigeria. Mar. Pet. Geol. 17, 959-974. 
Haacke, R.R., et al. 2008. High-flux gas venting in the East Sea, Korea, from analysis of 2D seismic reflection data, $6^{\text {th }}$ International Conference on Gas Hydrates (ICGH 2008), Vancouver. British Columbia, Canada.

630 Hammer, O., Webb, K.E., 2010. Piston coring of Inner Oslofjord Pockmarks, Norway: 631 constraints on age and mechanism. Nor. J. Geol. 90, 79-91.

632 Harrington, P.K., 1985. Formation of pockmarks by porewater escape, Geo-Mar. Lett. 5 (3), 633 193-197.

634 Hovland, M., 1983. Elongated depressions associated with pockmarks in the western slope 635 of the Norwegian trench. Mar. Geol. 51, 35-46.

636 Hovland, M., 1987. The formation of pockmarks and their potentiel influence on offshore 637 construction. Proc. of JSCE, 388/III-8 (Geotechnical eng.), 13-22.

638 Hovland, M., 1991. Large pockmarks, gas-charged sediments and possible clay diapirs in the 639 Skagerrak. Mar. Pet. Geol. 8, 311-316.

640 Hovland, M., Gallagher, J.W., 1997. Gas hydrate and free gas volumes in marine sediments: 641 Example from the Niger Delta front. Mar. Pet. Geol. 14, 313-328.

642 Hovland, M., et al. 2002. The significance of pockmarks to understanding fluid flow 643 processes and geohazards. Geofluids 2, 127-136.

644 Hovland, M., Judd, A. G. 1988. Seabed pockmarks and seepages: Impact on geology, 645 biology and the marine environment. London: Graham and Trotman 293 pp.

646 647

Hovland, M., et al. 1984. Characteristic features of pockmarks on the north sea floor and scotian shelf. Sedimentology $31,471-480$.

Hovland, M., et al. 2005. Complex pockmarks with carbonate-ridges off mid-Norway: Products of sediment degassing. Mar. Geol. 218, 191-206.

Hustoft, S., et al. 2007. High-resolution 3D-seismic data indicate focussed fluid migration pathways above polygonal fault systems of the mid-Norwegian margin. Mar. Geol. 245 (1-4), 89-106.

Jones, A.T., et al. 2010. Acoustic and visual characterization of methane-rich seabed seeps at Omakere Ridge on the Hikurangi Margin, New Zealand. Mar. Geol. 272,154-169.

Josenhans, H.W., et al. 1978. A side-scan sonar mosaic of pockmarks on the Scotian shelf. Can. J. Earth Sci. 15, 831-840.

Judd, A.G., Hovland, M., 1992. The evidence of shallow gas in marine sediments. Cont. Shelf Res. 12, 1081-1095.

Ker, S., et al. 2010. High-resolution seismic imaging in deep sea from a joint deeptowed/OBH reflection experiment: application to a Mass Transport Complex offshore Nigeria. Geophys. J. Int. 182, 1524-1542, doi:10.1111/j.1365-246X.2010.04700.x

King, L.H., MacLean, B., 1970. Pockmarks on the Scotian shelf. Geol Soc. Am. Bull. 81, 3141-3148. 
Lafuerza, S., et al. 2009. Overpressure within upper continental slope sediments from CPTU data, Gulf of Lion, NW Mediterranean Sea. Int. J. Earth Sci. (Geol Rundsch), doi:10.1007/s00531-008-0376-2.

Lafuerza, S., et al. 2012. Failure mechanisms of Ana Slide from geotechnical evidence, Eivissa Channel, Western Mediterranean Sea. Mar. Geol. 307-310, 1-21, doi:10.1016/j.margeo.2012.02.010.

Lee, H.J., 2009. Timing of occurrence of large submarine landslides on the Atlantic Ocean margin. Mar. Geol. 264, 53-64.

Løseth, H., et al. 2009. Hydrocarbon leakage interpreted on seismic data. Mar. Pet. Geol. 26, 1304-1319.

Løseth, H., et al. 2011. 1000 m long gas blow-out pipes. Mar. Pet. Geol. 28, 1040-1060.

Marsset, T., et al. 2010. High and very high resolution deep-towed seismic system: Performance and examples from deep water Geohazard studies. Deep-Sea Res. Part I, 57(4), 628-637, doi:10.1016/j.dsr.2010.01.001.

Maslin, M.A., et al. 2004. Linking continental slope failure to climate change: testing the clathrate gun hypothesis. Geology 32, 53-56.

Mathys, M., et al. 2005. Seismic characterisation of gas rich near surface sediments in the Arkona Basin, Baltic Sea. Mar. Geophys. Res. 26, 207-224.

McGuire, B., 2010. Potential for a hazardous geospheric response to projected future climate changes. Phil. Trans. R. Soc. A. 368, 2317-2345, doi:10.1098/rsta.2010.0080.

Morley, C.K., Guerin G., 1996. Comparison of gravity-driven deformation styles and behavior associated with mobile shales and salt. Tectonics 15, 6, 1154-1170.

Morley, C.K., et al. 2011. Deepwater fold and thrust belt classification, tectonics, structure and hydrocarbon prospectivity: a review. Earth-Sci. Rev. 104, 41-91.

Moss, J.L., Cartwright, J., 2010. 3D seismic expression of km-scale fluid escape pipes from offshore Namibia. Basin Res. 22, 481-501.

Moss, J.L., et al. 2012. The spatial pattern and drainage cell characteristics of a pockmark field, Nile Deep Sea Fan. Mar. Pet. Geol. 35, 321-336.

Netzeband, G.L., et al. 2010. The structures beneath submarine methane seeps: Seismic evidence from Opouawe Bank, Hikurangi Margin, New Zealand. Mar. Geol. 272, 57-70

Oomkens,E., 1974. Lithofacies relations in the Late Quaternary Niger Delta complex. Sedimentology 21, 195-222.

Papatheodorou, G., et al. 1993. Gas-charged sediments in the Aegean and Ionian Seas, Greece. Mar. Geol. 112, 171-184.

Paull, C., et al. 2002. Pockmarks off Big Sur, California. Mar. Geol. 181, 323-335.

Pilcher, R., Argent, J., 2007. Mega-pockmarks and linear pockmark trains on the West African continental margin. Mar. Geol. 244, 1-4, 15-32. 
Plaza-Faverola, A., et al. 2010. Fluid distributions inferred from P-wave velocity and reflection seismic amplitude anomalies beneath the Nyegga pockmark field of the midNorwegian margin. Mar. Pet. Geol. 27, 46-60.

704

705

706

707

708

709

710

711

712

713

714

715

716

717

718

719

720

721

722

723

724

725

726

727

728

729

730

731

732

733

734

735

736

737

738

739

Plaza-Faverola, A., et al. 2011. Repeated fluid expulsion through sub-seabed chimneys offshore Norway in response to glacial cycles. Earth Planet. Sci. Lett. 305, 297-308, doi:10.1016/j.epsl.2011.03.001.

Quidelleur, X., et al. 2008. Causal link between Quaternary palaeoclimatic changes and volcanic islands evolution. J. Geophys. Res. 35, L02303, doi:10.1029/2007GL031849.

Rao, Y., et al. 2001. Anomalous seismic reflections related to gas/gas hydrate occurences along the western continental margin of India. Geo-Mar. Lett. 21, 1-8.

Riboulot V., et al. 2012. Geometry and chronology of late Quaternary depositional sequences in the Eastern Niger Submarine Delta. Mar. Geol. 319-322, 1-20, doi:10.1016/j.margeo.2012.03.002.

Riboulot, V., et al. 2011a. Morphological signature of fluid flow seepage in the Eastern Niger Submarine Delta (ENSD). Houston, TX, USA. OTC 21744.

Riboulot, V., et al. 2011b. Obliquely migrating pockmarks formed in response to $100 \mathrm{kyr}$ and millennial-scale sea-level changes in the Gulf of Lions (Western Mediterranean), European Geosciences Union, 03-08 April 2011, Vienna, Austria, Abstract, 10295.

Richter, T.O., et al. 2006. The Avaatech XRF Core Scanner: technical description and applications to NE Atlantic sediments. In: Rothwell, R.G. (Ed.), New Techniques in Sediment Core Analysis. Geol. Soc. Spec. Publ. 267, 39-50.

Rodrigues, N., et al., 2009. Physical modelling of sand injectites. Tectonophysics 474, 610632.

Sager, W.W., et al. 2003. Geophysical signatures of mud mounds at hydrocarbon seeps on the Louisiana continental slope, northern Gulf of Mexico. Mar. Geol. 198, 97-132.

Schroot, B.M., et al. 2005. Surface and subsurface expressions of gas seepage to the seabed-examples from the Southern North Sea. Mar. Pet. Geol. 22 (4), 499-515.

Schroot, B.M., Schüttenhelm, R.T.E., 2003. Expressions of shallow gas in the Netherlands North Sea. Neth. J. Geosci. 82 (1), 91-105.

Smith, D.E., et al. 2011. The early Holocene sea level rise. Quaternary Sci. Rev. 30, 15-16, 1846-1860.

Soter, S., 1999. Macroscopic seismic anomalies and submarine pockmarks in the CorinthPatras rift, Greece. Tectonophysics 308, 275-290.

Sultan, N., et al. 2010, Hydrate dissolution as a potential mechanism for pockmark formation in the Niger Delta: J. Geophys. Res. 115, B08101, doi:10.1029/2010JB007453.

Sultan, N., et al. 2011. Dynamics of fault-fluid-hydrate system around a shale-cored anticline in deepwater Nigeria. J. Geophys. Res. 116, B12110, doi:10.1029/2011JB008218.

Sultan, N., et al. 2007a. Potential role of compressional structures in generating submarine slope failures in the Niger Delta. Mar. Geol. 240, 235-255. 
Sultan, N., et al. 2007b. Detection of free gas and gas hydrate based on 3D seismic data and cone penetration testing: An example from the Nigerian Continental Slope. Mar. Geol. 240, 235-255.

743 Sun, Q., et al. 2012. Shallow gas and focused fluid flow systems in the Pearl River Mouth

744 Basin, northern South China Sea. Mar. Geol. 315-318, 1-14

745 doi:10.1016/j.margeo.2012.05.003.

746 Talukder, A.R., 2012. Review of submarine cold seep plumbing systems: leakage to seepage 747 and venting. Terra Nova 24, 255-272, doi:10.1111/j.1365-3121.2012.01066.x.

748 Taylor, M.H., et al. 2000. Trapping and migration of methane associated with the gas hydrate 749 stability zone at the Blake Ridge Diapir: new insights from seismic data. Mar. Geol. 164, 7975089.

751 Trehu A.M., et al. 2004. Feeding methane vents and gas hydrate deposits at south Hydrate 752 Ridge. Geophys. Res. Lett. 31 (L23310), 1-4, doi:10.1029/2004GL021286.

753 Trincardi, F., et al. 2004. Evidence of soft-sediment deformation, fluid escape, sediment 754 failure and regional weak layers within the late-Quaternary mud deposits of the Adriatic Sea. 755 Mar. Geol. 213, 91-119.

756 Ussler III, W., et al. 2003. Submarine pockmarks: a case study from Belfast Bay, Maine. Mar. 757 Geol. 202, 175-192.

758 Vogt, P.R., et al. 1999. Ground-truthing 11-to 12-kHz side-scan sonar imagery in the 759 Norwegian-Greenland Sea -Part II: Probable diapirs on the Bear Island fan slide valley 760 margins and the Voring Plareau. Geo-Mar. Lett. 19, 111-130.

761 Wiener, R.W., et al. 2006. Mobile Shale Characteristics and Impact on Structural and Stratigraphic Evolution of the Niger Delta. AAPG/GSTT Hedberg conference, Port of Spain, Trinidad \& Tobago.

764 Waelbroeck, C., et al. 2002. Sea-level and deep water temperature changes derived from 765 benthic foraminifera isotopic records. Quaternary Sci. Rev. 21, 295-305. 


\section{Tables}

\begin{tabular}{|c|c|c|c|c|c|}
\hline Name & Tool & $\begin{array}{l}\text { Length } \\
\text { (mbsf) }\end{array}$ & $\begin{array}{l}\text { Water } \\
\text { depth }(m)\end{array}$ & $\begin{array}{l}\text { Date deployed } \\
\text { (DD/MM/YY) }\end{array}$ & Observations \\
\hline CS18 & $\begin{array}{l}\text { Calypso } \\
\text { piston corer }\end{array}$ & 17.76 & 762 & $20 / 05 / 2008$ & Silty layer at about $10 \mathrm{mbsf}$ \\
\hline CS31 & $\begin{array}{l}\text { Calypso } \\
\text { piston corer }\end{array}$ & 10.56 & 752 & $06 / 06 / 2008$ & Silty layers at about 6 and 17 mbsf \\
\hline СРT09S07 & CPTu & 30 & 761 & $10 / 05 / 2008$ & Cone resistance peak at $16 \mathrm{mbsf}$ \\
\hline СPT09S08 & CPTu & 30 & 761 & $11 / 05 / 2008$ & Cone resistance peak at 19 and $26 \mathrm{mbsf}$ \\
\hline PZS13 & $\begin{array}{l}\text { Piezometer } \\
5 \text { sensors }\end{array}$ & 12 & 761 & $20 / 05 / 2008$ & $\begin{array}{l}\text { Deployment duration: } 389 \mathrm{~d} \\
\text { Depth of sensors (mbsf): P1 - 0.83, P2 - 3.88, } \\
\text { P3 - 6.93, P4 - 9.98, P5 - } 11.48\end{array}$ \\
\hline PZS14 & $\begin{array}{l}\text { Piezometer } \\
5 \text { sensors }\end{array}$ & 12 & 753 & $20 / 05 / 2008$ & $\begin{array}{l}\text { Deployment duration: } 412 \mathrm{~d} \\
\text { Depth of sensors (mbsf): } \mathrm{P} 1-0.83, \mathrm{P} 2-3.88 \text {, } \\
\text { P3 - } 6.93, \mathrm{P} 4-9.98, \mathrm{P} 5-11.48\end{array}$ \\
\hline
\end{tabular}

768 Table 1: Basic information about Calypso sediment cores, piezocone tests (CPTu) and 769 piezometers. 


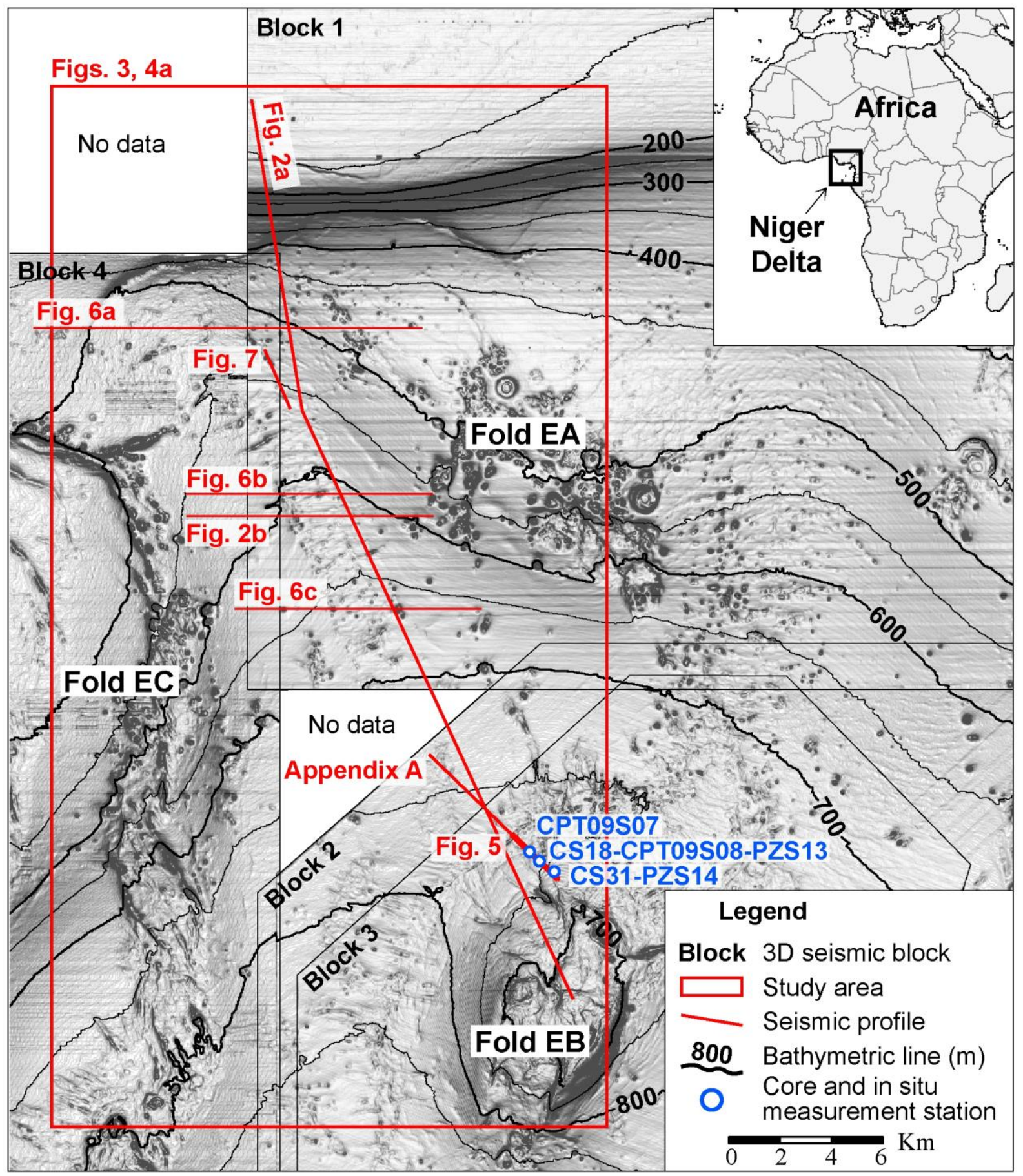

Figure 1: Location map of the Eastern Niger Submarine Delta. The seafloor dip map of the 773 study area with 50-m spaced bathymetric contour has a $25 \mathrm{~m}$ horizontal resolution (modified 774 from Riboulot et al., 2012). This map is generated from seismic seabed picking with Sismage software provided by Total. The red lines and boxes are the figure location presented in this paper. 

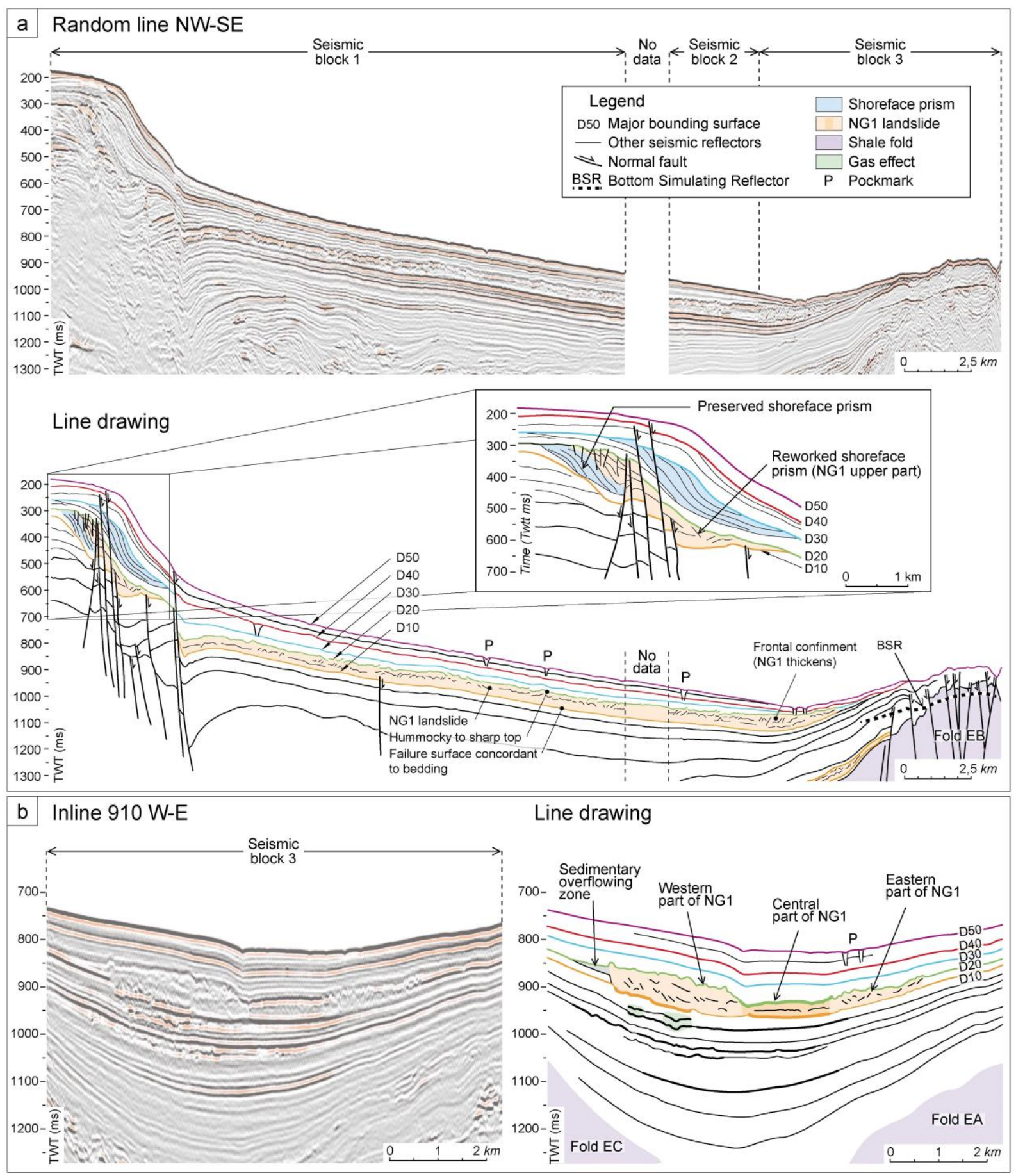

779 Figure 2: Geometry of the stratigraphic organization of the ENSD with NG1 landslide. a: 780 Uninterpreted regional random line oriented NW-SE, from reprocessed exploration 3D 781 seismic data, showing depositional sequences from the outer continental shelf to the upper continental slope. This line shows the structural organization of the study area (location in Fig. 1). The NG1 landslide affects the outer shelf and finishes on the shale fold EB. The Dxx seismic reflectors represent regional surfaces marking lowstands. The close up view of the outer shelf shows the stacking pattern of shoreface prisms detailed in Riboulot et al., (2012) and the upper part of the NG1 lanslide affecting a shoreface prism. b: Transversal inline 910 oriented W-E, from reprocessed exploration 3D seismic data, showing NG1 with its 3 internal units. The D60 seismic reflector is in blue, and the NG1 landslide in orange. 


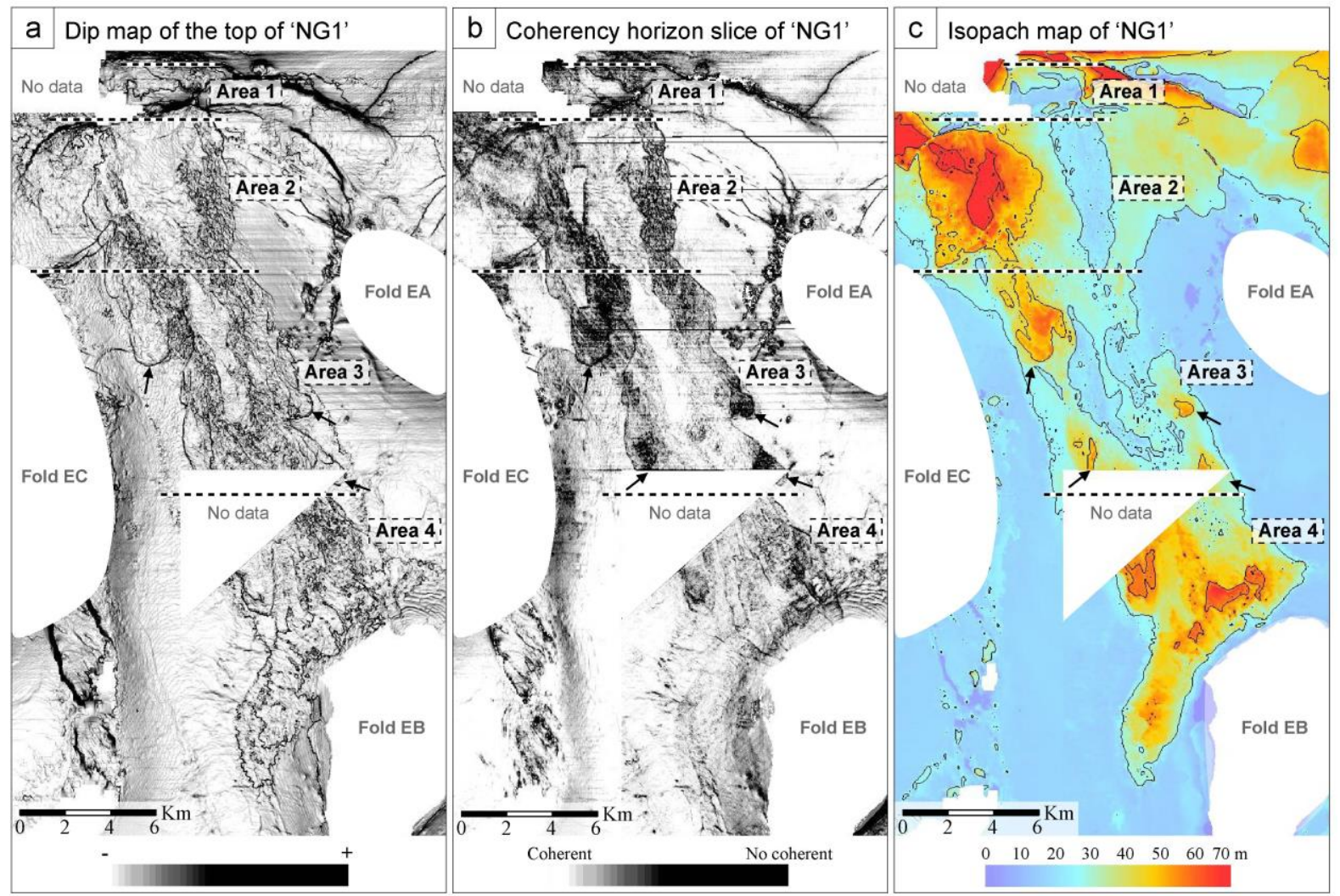

Figure 3: NG1 landslide characteristics illustrated by seismic attribute maps extracted from Sismage software. a: Seismic reflection dip magnitude map of the top of the NG1 landslide. $\mathrm{b}$ : Chaotism map exhibiting a variety of forms including the extent of NG1 landslide and the remained character of the internal units of NG1. c: Isopach map of the Top 'NG1' horizon Base 'NG1' horizon interval, showing the sedimentary accumulation heterogeneities due to the slide (dashed lines separate Areas 1 to 4 ). 

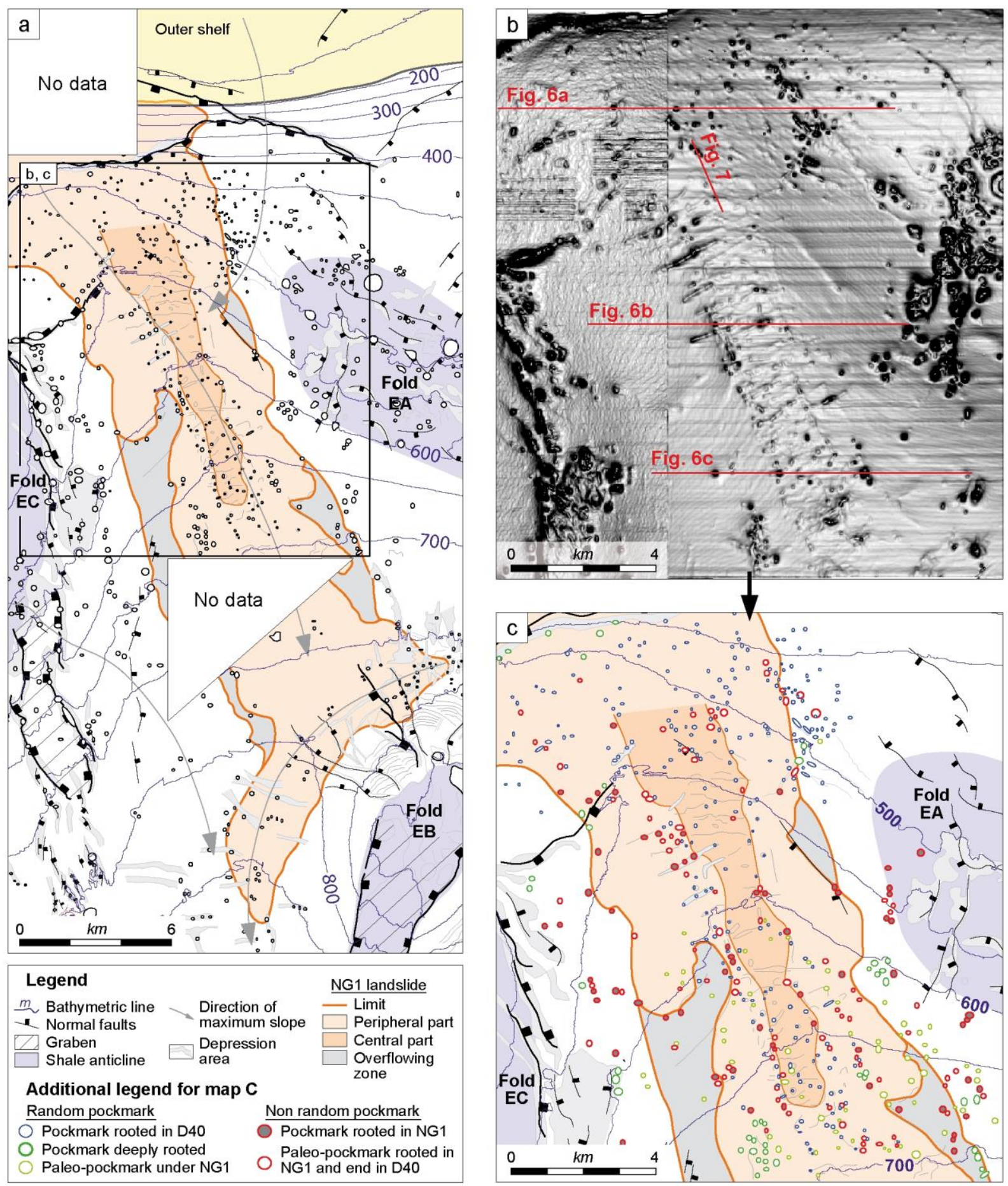

799 Figure 4: a: Geomorphologic map of NG1 landslide and surrounding area obtained from the 800 interpretation of the bathymetric map and of the 3D seismic data. Faults affecting the seabed 801 are in black, pockmarks in black and white, shale folds in grey and outer continental shelf in 802 yellow. b: Dip map of the study area with location of the following figures in red. c: 803 Geomorphologic map of the study area showing the different group of pockmarks described 804 in the study area from the interpretation of 3D seismic data. The non random pockmarks (in 805 red) are rooted in the NG1 internal discontinuities, while the random pockmarks (in blue) are 806 807 connected to D40 reflector and the random pockmarks (in green) are more deeply rooted. 


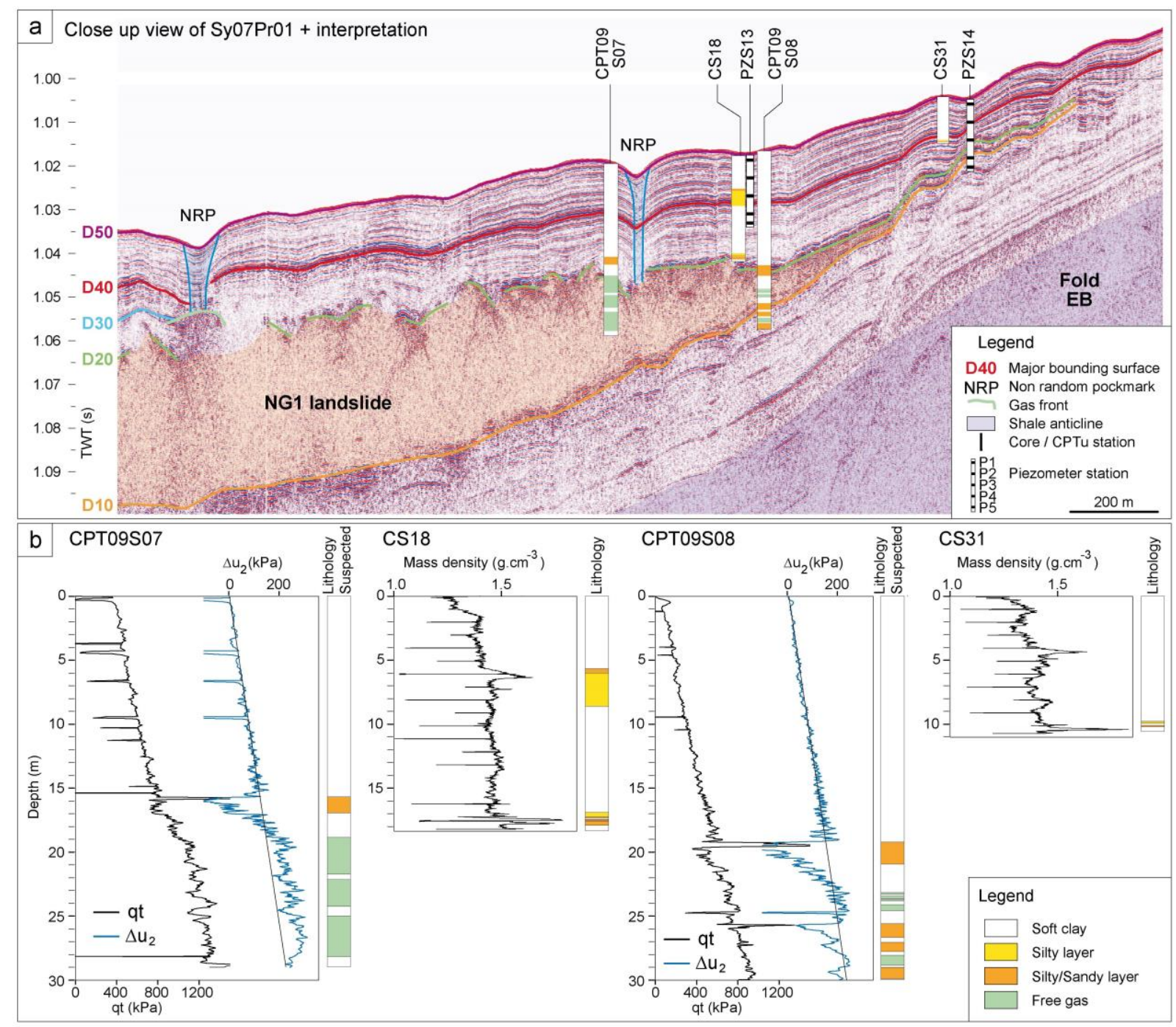

809 Figure 5: a: Close up view of the 2D HR seismic lines presented in Appendix B with 810 interpreted piezocone and core data. NRP $=$ Non Random Pockmark. b: Corrected cone 811 resistance qt and excess pore pressure $\Delta \mathrm{u} 2$ versus depth from sites CPT09S07 and 812 CPT09S08. Mass density values versus depth and lithology presented for cores CS18 and 813 CS31. See text for details. 

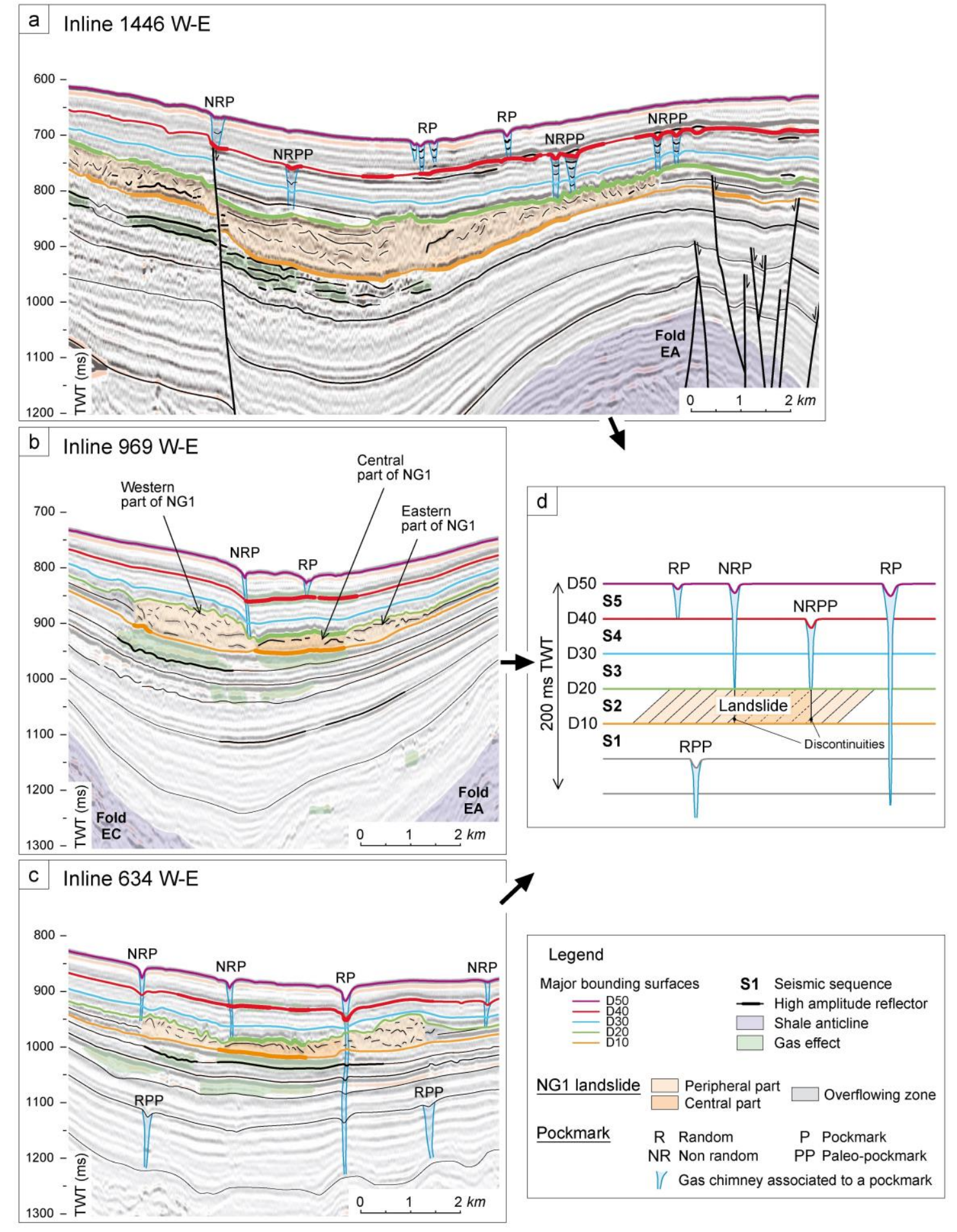

816 Figure 6: a: Seismic transversal inline 1446 oriented W-E, from reprocessed exploration 3D 817 seismic data, with its seismic interpretation showing: (1) non random pockmarks connected 818 with NG1 landslide ending up in D40 reflector, and (2) random pockmarks rooted in the D40 819 reflector. b: Seismic transversal inline 969 oriented $W-E$, from reprocessed exploration 3D seismic data, with its seismic interpretation showing: (1) non random pockmarks rooted in NG1 landslide internal discontinuities, and (2) pockmarks rooted in the D40 reflector. c: Seismic transversal inline 634 oriented W-E, from reprocessed exploration 3D seismic data, with its seismic interpretation showing: (1) non random pockmarks rooted in NG1 landslide internal discontinuities, (2) random paleo-pockmarks, and (3) random pockmarks deeply rooted. d: Summary of organization of the stratigraphic pattern and location of all types of pockmarks observed in the study area. See text for details. 


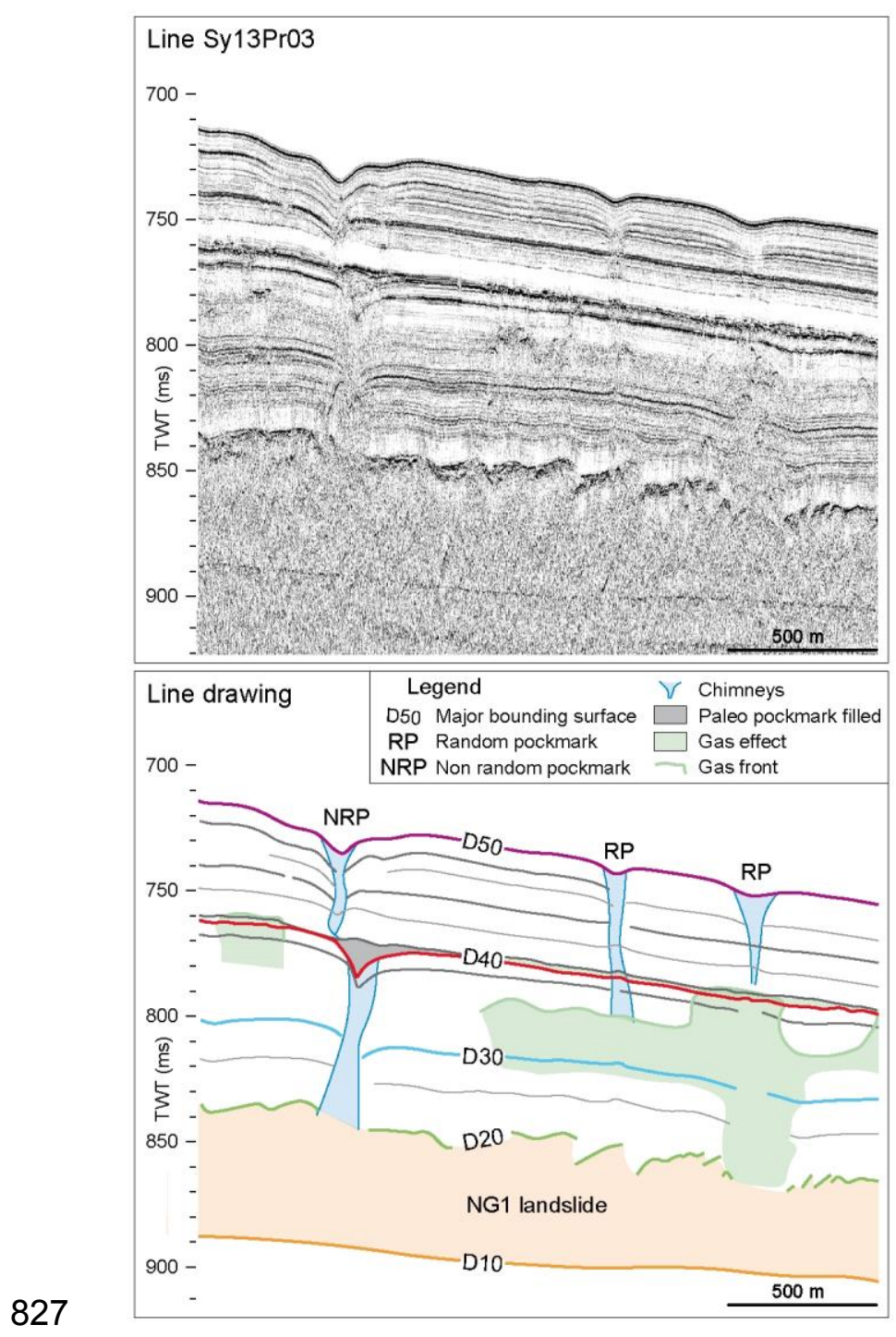

828 Figure 7: 2D HR seismic lines acquired with the SYSIF system along the same track of the 829 seismic line presented in Figure 2, showing more details about the features described and 830 the precise location of fluids within sediment. 


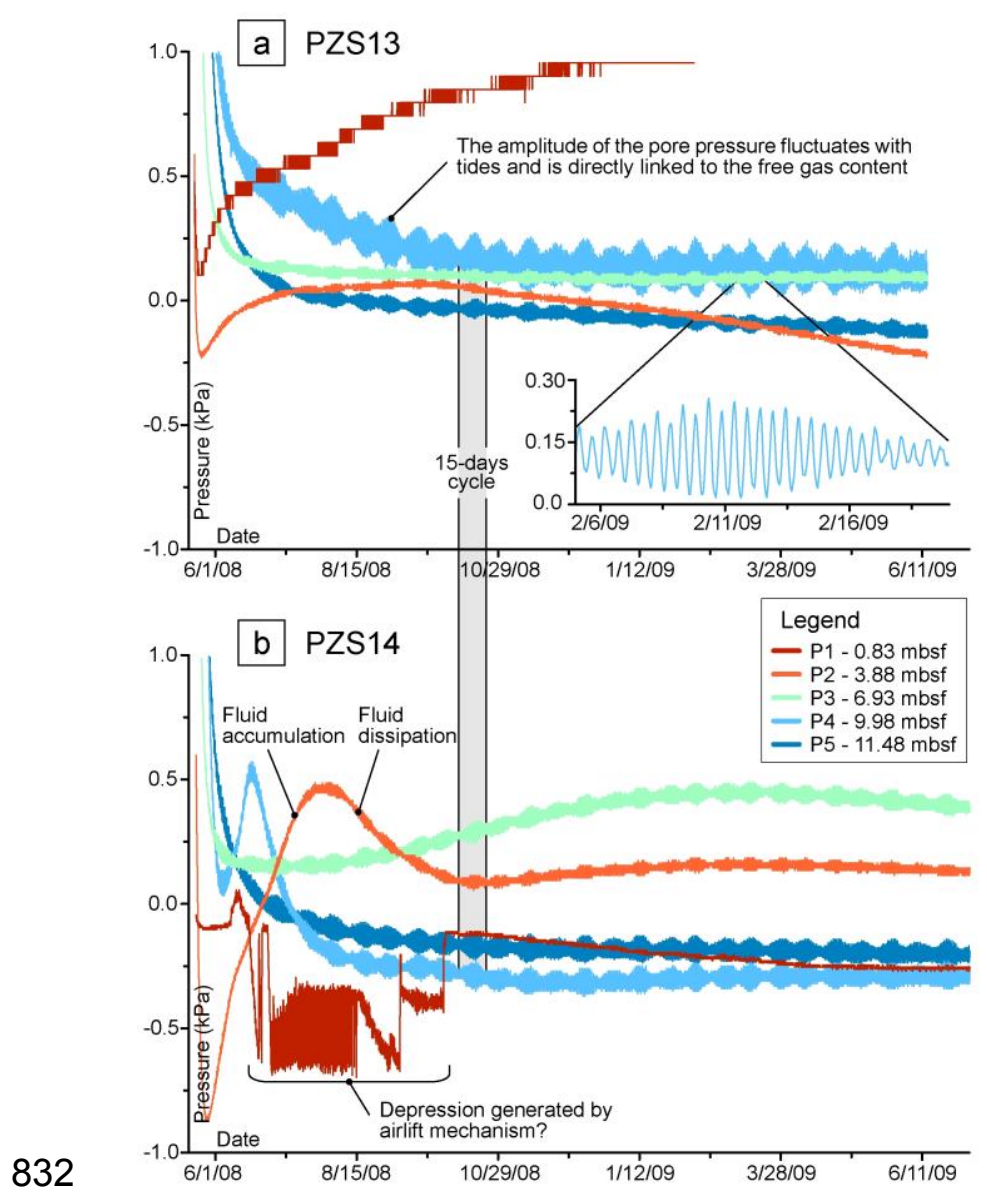

833 Figure 8: a: Excess pore water pressure of the 5 sensors (P1 to P5) of PZS13, b: excess 834 pore water pressure of the 5 sensors (P1 to P5) of PZS14, and c: excess pore water 835 pressure of 2 sensors (P1 and P2) of PZS14. See text for details. 


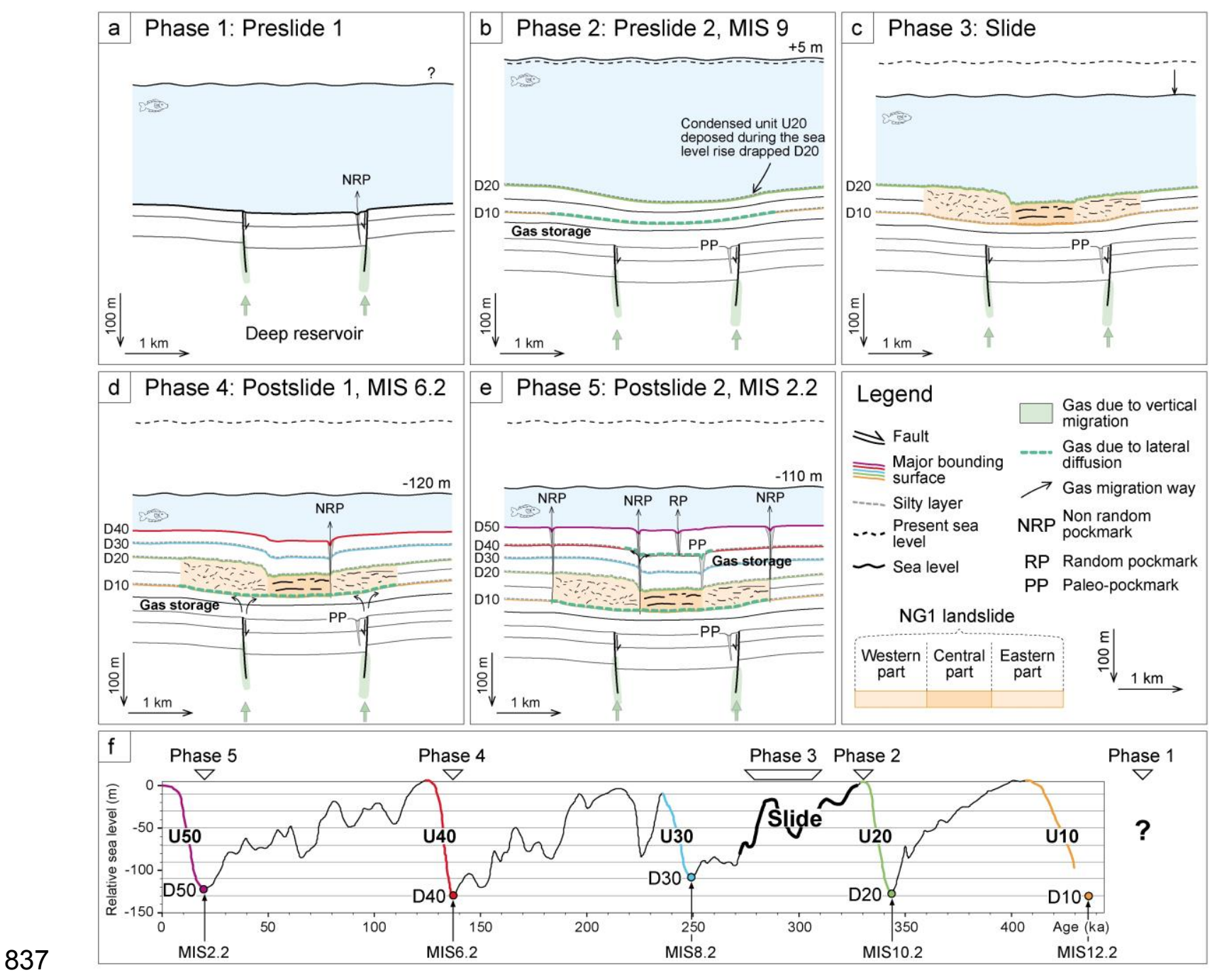

838 Figure 9: Conceptual model (Idealized scenario) of development of pockmark field controlled 839 by fluid seepages throughout a landslide. The scenario, valid for the observations made in 840 this paper, is composed of 5 phases (a, b, c, d, e) detailed in the discussion. $\mathrm{f}$ : Sea-level 841 change curve (Waelbroeck et al., 2002) indicates the timing of phases 1 to 5 of pockmarks 842 and landslide formation. 


\section{Supplementary material}

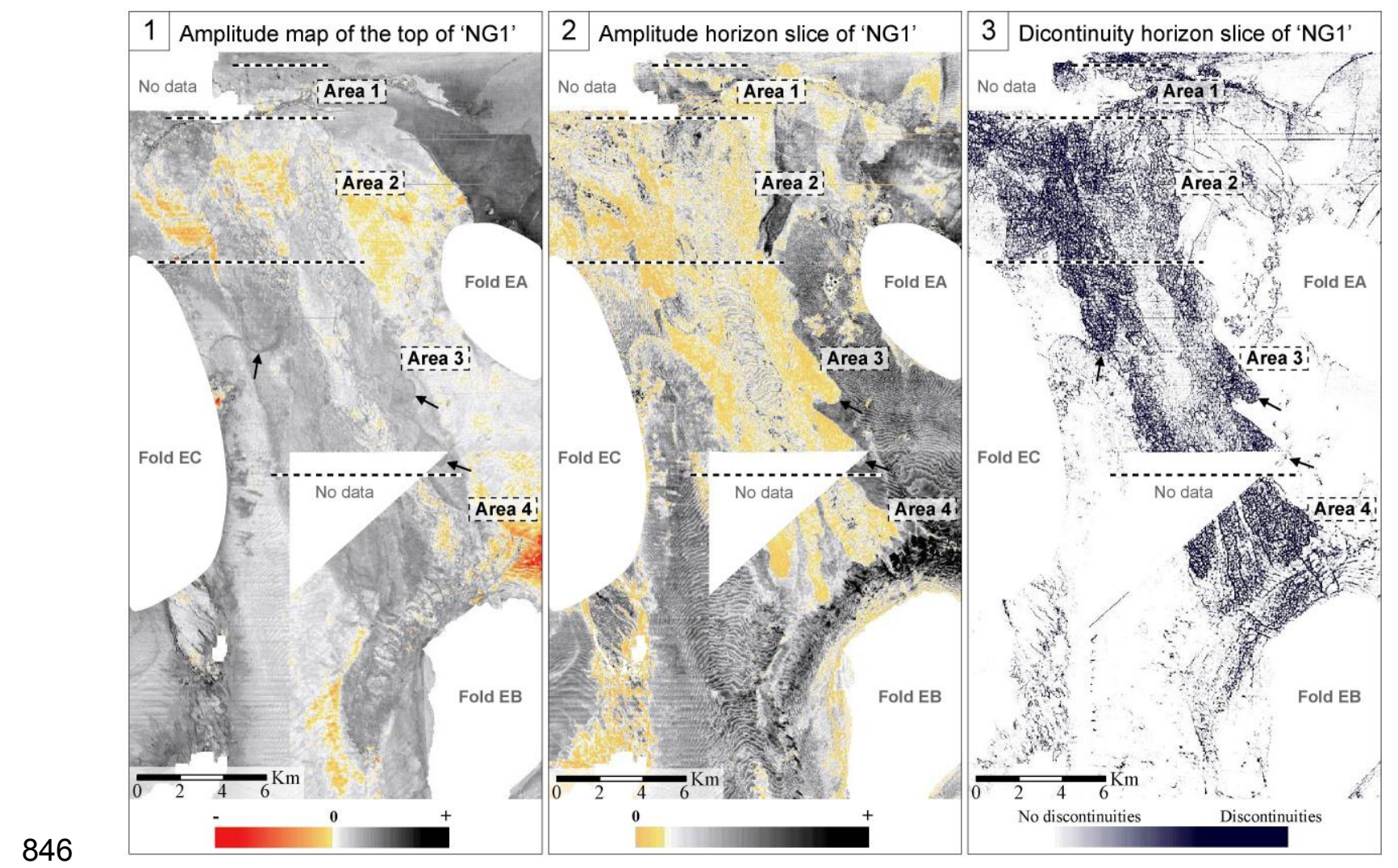

847 Appendix A: NG1 landslide characteristics illustrated by seismic attribute maps extracted 848 from Sismage software. 1: Seismic reflection amplitude map of the top of the NG1 landslide. 849 2: Amplitude map showing the stratification of the central unit and the reworked character of 850 the western and the eastern units. 3: Fault map showing faults, pockmarks and the 851 discontinuities within NG1 (dashed lines separate Areas 1 to 4). 


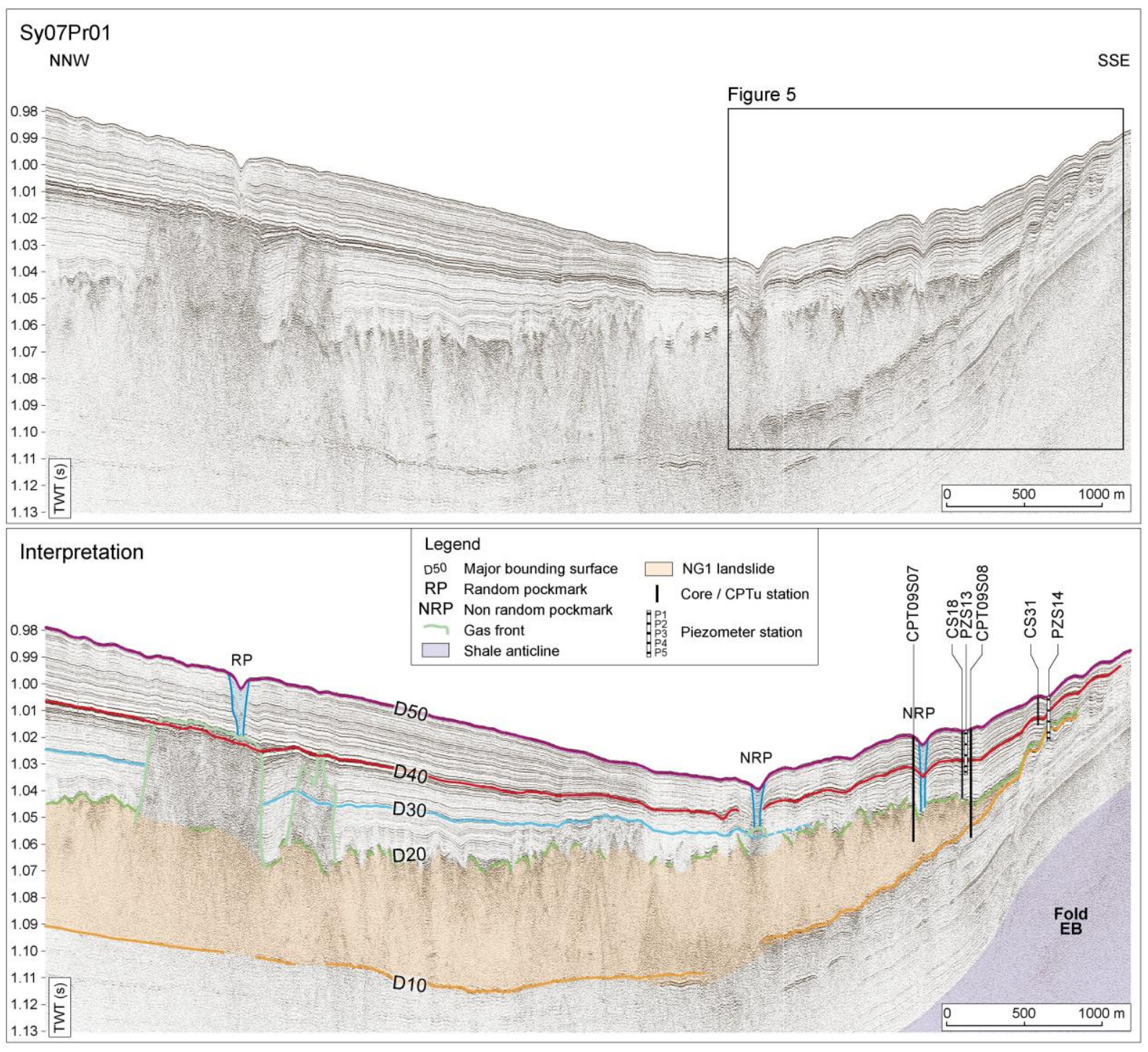

854 Appendix B: 2D HR seismic lines acquired with the SYSIF system along the same track of 855 the seismic line presented in Figure 5 with location of piezocone and core stations. The high amplitude reflectors named Dxx are interpreted as coarse grain layers from coring and in situ measurements. D20 reflector on top of NG1 is discontinuous with local deformation and disruption. 